\title{
Determination of Provenance and Tectonic Settings of Niger Delta Clastic Facies Using Well-Y, Onshore Delta State, Nigeria
}

\author{
S. O. Oni, A. S. Olatunji, and O. A. Ehinola \\ Department of Geology, University of Ibadan, Ibadan 200284, Oyo State, Nigeria \\ Correspondence should be addressed to S. O. Oni; talk2nicesam@hotmail.com
}

Received 25 August 2014; Revised 8 November 2014; Accepted 10 November 2014; Published 28 December 2014

Academic Editor: Franco Tassi

Copyright (C) 2014 S. O. Oni et al. This is an open access article distributed under the Creative Commons Attribution License, which permits unrestricted use, distribution, and reproduction in any medium, provided the original work is properly cited.

\begin{abstract}
Provenance analysis serves to reconstruct the predepositional history of a sediment/sedimentary rock. This paper focuses on the reconstruction of the provenance and tectonic settings of the Niger delta clastic facies using geochemical approach. The main types of geochemical tests include major, trace, and rare earth element (REE) tests. Twenty-one samples of shales and sandstones units were purposely collected from a depth between 1160 and $11,480 \mathrm{~m}$, grinded, pulverized, and sieved with a $<75 \mu \mathrm{m}$. About $5 \mathrm{~g}$ was packed and sent to Acme analytical Laboratory Ltd., Vancouver, Canada. The analyses were carried out by both induced coupled plasma-mass spectrometry (ICP-MS) and induced coupled plasma-emission spectrometry (ICP-ES). Bulk-rock geochemistry of major oxides, trace elements, and rare earth elements was utilized for the provenance and tectonic setting determination. Based on the discrimination diagram for major oxides, the probable provenance of the south eastern Delta clastic sediments was mainly of the active continental margins. The bivariate plots of La versus Th, La/Y versus Sc/Cr, and Ti/Zr versus La/Sc and the trivariate plots of La-Th-Sc, Th-Sc-Zr/10, and Th-Co-Zr/10 are all plotted on the fields of active continental margin sediments which is consistent with the known actively opening of a failed arm of triple junction. The trace elements and REE analysis indicates that they are virtually Fe-rich, lithic/quartz arkosic sandstones. The normalizing factors used for the REE are Wakita chondrite. Their rare earth elements (REE) pattern displays high light REE/heavy REE (LREE/HREE) ratio, flat HREE, and a significant negative Eu anomaly which correlate well with the UCC and PAAS average composition. The source area may have contained felsic igneous rocks.
\end{abstract}

\section{Introduction}

The samples were taken from Y-field in Niger delta. The coordinates of the study area were not given because of the proprietary nature of the data but the estimated location is shown in Figure 1. The Niger delta extends from about longitudes $3^{\circ} \mathrm{E}$ and $9^{\circ} \mathrm{E}$ and latitudes $4^{\circ} 30^{\prime} \mathrm{N}$ to $5^{\circ} 21^{\prime} \mathrm{N}$. The Niger delta is located in the southern part of Nigeria. The Niger delta is situated in the Gulf of Guinea, which northwards merges with the structural basin in the Benue and middle Niger terrain holding thick marine paralic and continental sequence. The onshore portion of the Niger delta province is delineated by the geology of southern Nigeria and southwestern Cameroon. The Niger delta was formed as a result of basement tectonics related to the crustal divergence during the late Jurassic to cretaceous continental rifting of Gondwanaland that led to the separation of South American African continents. The Niger delta is large arcuate to lobate tropical constructive wave of dominated type. Active deposition is presently occurring simultaneously in these depobelts under fluviatile conditions where there is interplay between terrestrial and marine influences.

The Niger delta basin to date is the most prolific and economic sedimentary basin in Nigeria. It is an excellent petroleum province. The Niger delta is situated in the Gulf of Guinea and extends throughout the Niger delta province. From the Eocene to the present, the delta has prograded southwestward, forming depobelts that represent the most active portion of the delta at each stage of its development [1]. These depobelts form one of the largest regressive deltas in the world with an area of some $300,000 \mathrm{~km}^{2}$ [2], a sediment volume of $500,000 \mathrm{~km}^{3}$ [3], and a sediment thickness of over $10 \mathrm{~km}$ in the basin depocenter [4].

The Niger delta province contains only one identified petroleum system $[2,5]$. This system is referred to here as the tertiary Niger delta (Akata-Agbada) petroleum system. 

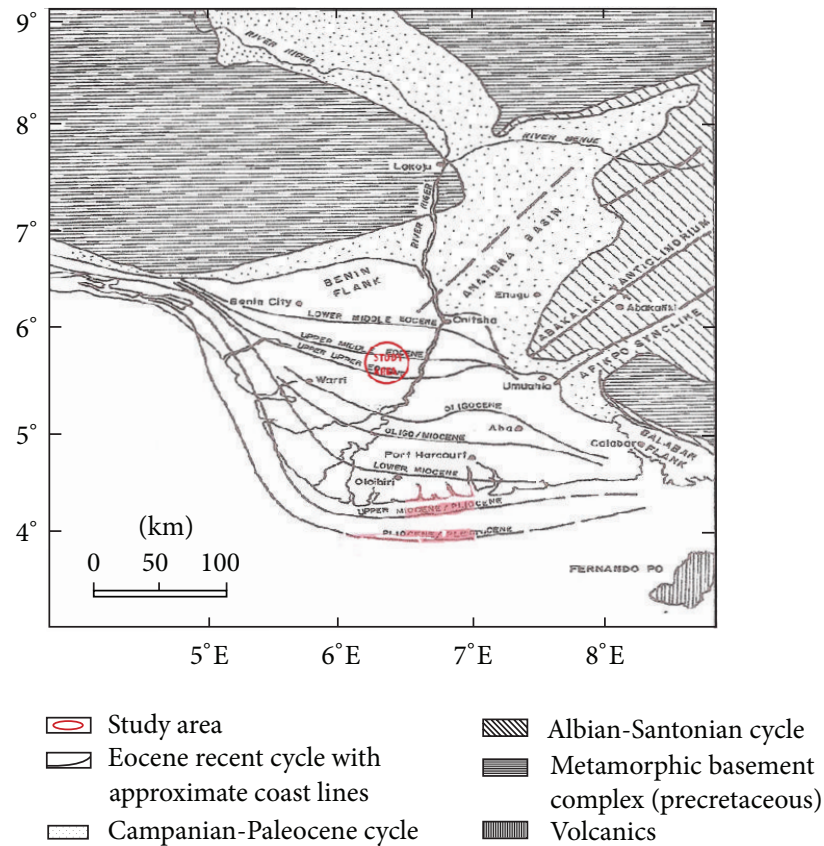

FIGURE 1: Generalized and simplified geological map of Niger delta basin as obtained from http://www.intechopen.com.

The maximum extent of the petroleum system coincides with the boundaries of the province. The minimum extent of the system is defined by the areal extent of fields and contains known resources (cumulative production plus proved reserves) of 34.5 billion barrels of oil (BBO), 93.8 trillion cubic feet of gas (TCFG), and 14.9 billion barrels of oil equivalent (BBOE) [6]. Currently, most of this petroleum is in fields that are onshore or on the continental shelf in waters less than 200 meters deep and occurs primarily in large, relatively simple structures. Among the provinces ranked in the U.S. Geological Survey's World Energy Assessment [7], the Niger delta province is the twelfth richest in petroleum resources, with $2.2 \%$ of the world's discovered oil and $1.4 \%$ of the world's discovered gas [6].

\section{Materials and Methods}

2.1. Sample Collection and Analysis. Twenty-one core samples were collected and subjected to inorganic analysis which includes major oxides, trace elements, and rare earth element. The samples are first dried. To avoid contamination, the samples are then washed in deionized water and dried again. After preparation, the samples are grinded and pulverized. Sample reduction entails comminuting by sieving or crushing and grinding. Standard procedure at most laboratories is to sieve soils and sediments to $<75 \mu \mathrm{m}$. The samples are thus sieved with $<75 \mu \mathrm{m}$. This is because sample preparation must reduce the sample volume to a size suitable for analysis yet preserves the bulk geochemical signature of the larger body. About $3 \mathrm{~g}$ of the pulverized sample was then packed in a suitable bag and sent to Acme labs, Vancouver, Canada, for analysis.

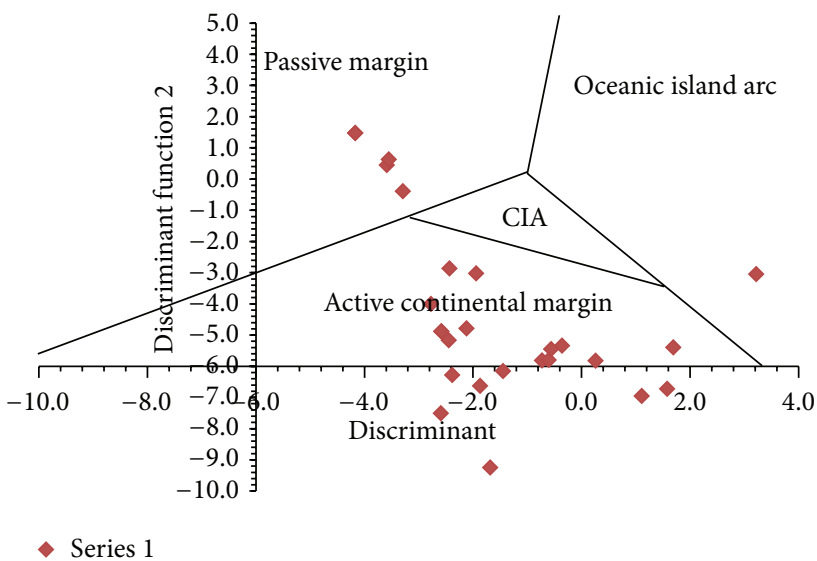

FIgUre 2: The plot of discriminant 2 against discriminant 1; the discriminant function diagram for sandstones (after [8]), showing fields for sandstones from passive continental margins, oceanic island arcs, continental island arcs, and active continental margins. The CIA at the centre represents continental island arc.

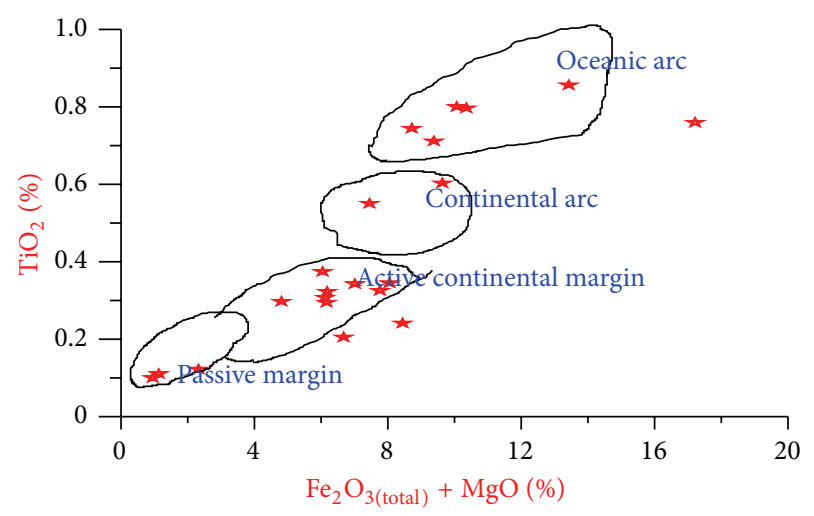

FIgURE 3: Bivariate plot of $\mathrm{TiO}_{2}$ versus $\left(\mathrm{Fe}_{2} \mathrm{O}_{3}+\mathrm{MgO}\right)$ diagrams for sandstones (after [8]). The fields are oceanic island arc, continental island arc, active continental margin, and passive margins.

\section{Results}

3.1. Tectonic Settings of Niger Delta Based on Major Oxides. See Table 1 and Figures 2 and 3.

3.2. Results and Discussion. Knowledge of the tectonic setting of a basin is important for the exploration of petroleum and other resources as well as for paleogeography. Some authors have described the usefulness of major element geochemistry of sedimentary rocks to infer tectonic setting based on discrimination diagrams (e.g., $[8,9]$ ). This is because plate tectonics processes impart distinctive geochemical signature to sediments in two separate ways. Firstly, tectonic environments have distinctive provenance characteristics and secondly they are characterized by distinctive sedimentary process.

Bhatia [8] proposed major element geochemical criteria to discriminate plate tectonic settings for sedimentary basins from identified well-defined sandstone suites. He compiled 
TABLE 1: Table of the eleven major element oxides in percentages.

\begin{tabular}{|c|c|c|c|c|c|c|c|c|c|c|c|c|c|}
\hline Samples depth & Lithology & $\begin{array}{c}\mathrm{FeO} \\
\% \\
\end{array}$ & $\begin{array}{c}\mathrm{Fe}_{2} \mathrm{O}_{3} \\
\% \\
\end{array}$ & $\begin{array}{c}\mathrm{CaO} \\
\% \\
\end{array}$ & $\begin{array}{c}\mathrm{P}_{2} \mathrm{O}_{5} \\
\% \\
\end{array}$ & $\begin{array}{c}\mathrm{MgO} \\
\% \\
\end{array}$ & $\begin{array}{c}\mathrm{TiO}_{2} \\
\% \\
\end{array}$ & $\begin{array}{c}\mathrm{Al}_{2} \mathrm{O}_{3} \\
\% \\
\end{array}$ & $\begin{array}{c}\mathrm{Na}_{2} \mathrm{O} \\
\% \\
\end{array}$ & $\begin{array}{c}\mathrm{K}_{2} \mathrm{O} \\
\% \\
\end{array}$ & $\begin{array}{c}\mathrm{MnO} \\
\% \\
\end{array}$ & $\begin{array}{c}\mathrm{SiO}_{2} \\
\% \\
\end{array}$ & $\begin{array}{c}\text { Total } \\
\% \\
\end{array}$ \\
\hline $1160-1180$ & Sand & 0.5 & 0.5 & 1.1 & 0.0 & 0.1 & 0.1 & 1.7 & 0.2 & 0.2 & 0.0 & 95.5 & 100.0 \\
\hline $1560-1580$ & Sand & 0.4 & 0.5 & 0.6 & 0.0 & 0.1 & 0.1 & 1.5 & 0.4 & 0.3 & 0.0 & 96.0 & 100.0 \\
\hline 1960-1980 & Sand & 1.0 & 1.1 & 0.8 & 0.0 & 0.1 & 0.1 & 1.7 & 0.6 & 0.6 & 0.0 & 93.8 & 100.0 \\
\hline $2960-2980$ & Shale & 2.2 & 2.4 & 0.4 & 0.0 & 0.2 & 0.3 & 5.1 & 1.8 & 1.7 & 0.0 & 85.8 & 100.0 \\
\hline $3960-3980$ & Shale & 4.3 & 4.7 & 0.4 & 0.1 & 0.4 & 0.7 & 11.1 & 2.6 & 3.0 & 0.0 & 72.7 & 100.0 \\
\hline $4560-4580$ & Shale & 3.9 & 4.4 & 0.4 & 0.1 & 0.4 & 0.7 & 13.5 & 3.3 & 3.1 & 0.0 & 70.1 & 100.0 \\
\hline $5460-5480$ & Shale & 3.6 & 4.0 & 0.2 & 0.0 & 0.1 & 0.3 & 3.8 & 4.6 & 2.9 & 0.0 & 80.4 & 100.0 \\
\hline $5760-5780$ & Shale & 4.7 & 5.2 & 0.2 & 0.1 & 0.1 & 0.8 & 6.5 & 4.5 & 2.9 & 0.0 & 74.9 & 100.0 \\
\hline $6160-6180$ & Shale & 3.4 & 3.8 & 0.7 & 0.1 & 0.2 & 0.6 & 11.0 & 3.7 & 2.8 & 0.0 & 73.8 & 100.0 \\
\hline $7060-7080$ & Sand & 2.9 & 3.2 & 0.7 & 0.2 & 0.1 & 0.3 & 3.1 & 6.0 & 4.3 & 0.0 & 79.2 & 100.0 \\
\hline $7260-7280$ & Sand & 2.8 & 3.2 & 0.7 & 0.1 & 0.1 & 0.3 & 4.4 & 6.8 & 4.7 & 0.0 & 76.9 & 100.0 \\
\hline $7560-7580$ & Sand & 3.2 & 3.6 & 0.6 & 0.1 & 0.2 & 0.3 & 5.4 & 6.0 & 4.5 & 0.0 & 76.0 & 100.0 \\
\hline $7760-7780$ & Shale & 4.3 & 4.8 & 0.8 & 0.1 & 0.6 & 0.6 & 9.0 & 1.9 & 3.1 & 0.0 & 74.7 & 100.0 \\
\hline $7960-7980$ & Shale & 2.8 & 3.1 & 0.8 & 0.1 & 0.2 & 0.3 & 5.4 & 4.7 & 3.9 & 0.0 & 78.6 & 100.0 \\
\hline $8060-8080$ & Shale & 2.9 & 3.2 & 1.4 & 0.0 & 0.6 & 0.2 & 3.5 & 1.0 & 1.7 & 0.0 & 85.5 & 100.0 \\
\hline $8160-8180$ & Sand & 3.0 & 3.4 & 3.1 & 0.1 & 1.6 & 0.3 & 4.8 & 0.7 & 1.7 & 0.0 & 81.2 & 100.0 \\
\hline $8560-8580$ & Sand & 3.8 & 4.2 & 1.7 & 0.1 & 0.4 & 0.2 & 3.9 & 1.0 & 1.6 & 0.0 & 82.9 & 100.0 \\
\hline $8960-8980$ & Shale & 4.7 & 5.2 & 0.9 & 0.1 & 0.4 & 0.8 & 11.7 & 0.9 & 2.5 & 0.0 & 72.7 & 100.0 \\
\hline $10,360-10,380$ & Shale & 2.7 & 3.0 & 0.5 & 0.1 & 0.3 & 0.4 & 6.0 & 1.3 & 2.8 & 0.0 & 82.8 & 100.0 \\
\hline $11,060-11,080$ & Shale & 7.7 & 8.6 & 0.7 & 0.2 & 0.9 & 0.8 & 13.5 & 1.2 & 2.7 & 0.1 & 63.6 & 100.0 \\
\hline $11,460-11,480$ & Shale & 6.1 & 6.8 & 0.5 & 0.1 & 0.5 & 0.9 & 14.6 & 1.1 & 2.1 & 0.1 & 67.2 & 100.0 \\
\hline
\end{tabular}

the average chemical compositions of medium- to finegrained sandstones (e.g., arkose, greywacke, lithic arenite, and quartz arenite) and modern sands from various regions of the world and used these average values to propose discrimination diagrams.

Bhatia [8] used these diagrams to infer the tectonic settings of five Paleozoic sandstone suites of eastern Australia. He then proposed discriminant functions (functions 1 and 2) by using 11 major element oxides (shown in Table 1) as discriminant variables to construct a territorial map for the tectonic classification of sandstones. Discriminant scores of functions 1 and 2 [8] were calculated from the unstandardized function coefficient and the actual abundance of major element oxides in the average. Bhatia [8] considered the tectonic setting of sandstones that he studied and generally concluded that sedimentary basins may be assigned to the following tectonic settings based on the 11 major oxides (Table 1):

(1) oceanic arc: fore arc or back arc basins, adjacent to volcanic arcs developed on oceanic or thin continental crust;

(2) continental island arc: inter arc, fore arc, or back arc basins adjacent to a volcanic arc developed on a thick continental crust or thin continental margins;

(3) active continental margin: Andean type basin developed on or adjacent to thick continental margins and strike-slip basins also developed in this environment;

(4) passive continental margin: rifted continental margins developed on thick continental crust on the edges of continents and sedimentary basins on the trailing edge of continent.

These diagrams are used for the recovered sediments from well-Y, southwestern Niger delta in order to determine the tectonic setting of the area in Figure 2.

Bhatia [8] proposed a discrimination diagram based on a bivariate plot of first and second discriminant functions of major element analysis. The sandstones were chosen to represent the four different tectonic settings, assigned on the basis of comparison with modern sediments as shown in Figure 2. When this diagram is used, samples with high content of $\mathrm{CaO}$ as carbonate must be corrected for carbonate content. This discrimination diagram is used to classify the suites of various samples into different tectonic settings. The discriminant functions are

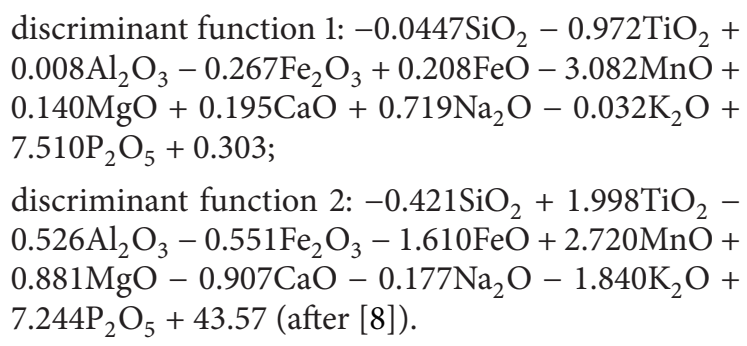

The discriminant plot is shown in Figure 2.

Modern sandstones from oceanic and continental arcs and active and passive continental margins have variable composition, especially in their $\mathrm{Fe}_{2} \mathrm{O}_{3}+\mathrm{MgO}, \mathrm{Al}_{2} \mathrm{O}_{3} / \mathrm{SiO}_{2}$, $\mathrm{K}_{2} \mathrm{O} / \mathrm{Na}_{2} \mathrm{O}$, and $\mathrm{Al}_{2} \mathrm{O}_{3} /\left(\mathrm{CaO}+\mathrm{Na}_{2} \mathrm{O}\right)$ contents. Bhatia [8] 


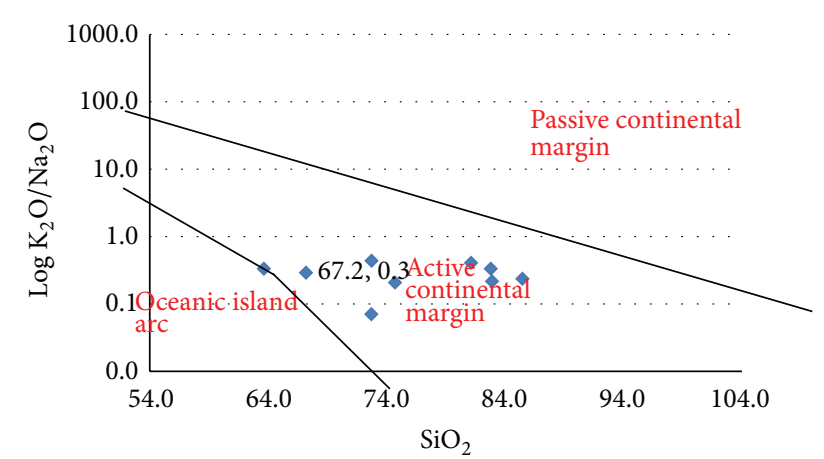

FIgure 4: The plot of $\log \mathrm{K}_{2} \mathrm{O} / \mathrm{Na}_{2} \mathrm{O}-\mathrm{SiO}_{2}$ discrimination diagrams of Roser and Korsch [9] for sandstone mudstone suites showing the different tectonic settings.

used this chemical variability to discriminate between different tectonic settings on a series of bivariate plots. Figure 3 shows the discrimination diagrams for sandstones (after [8]) based upon a bivariate plot of $\mathrm{TiO}_{2}$ versus $\left(\mathrm{Fe}_{2} \mathrm{O}_{3}+\mathrm{MgO}\right)$. The fields are oceanic island arc, continental island arc, active continental margin, and passive margins.

Roser and Korsch tectonic settings determinant diagrams are as follows: the three tectonic settings, passive continental margin $\mathrm{PM}$, active continental margin $\mathrm{ACM}$, and oceanic island $\operatorname{arc}(\mathrm{ARC})$ are recognized on the $\mathrm{K}_{2} \mathrm{O} / \mathrm{Na}_{2} \mathrm{O}-\mathrm{SiO}_{2}$ discrimination diagrams of Roser and Korsch [9] for sandstone mudstone suites as shown in Figure 4. Where sediments are rich in carbonate components, the analysis was recalculated as $\mathrm{CaCO}_{3}$-free. Failure to do this will shift samples to lower $\mathrm{SiO}_{2}$ values and from passive margin field into volcanic arc field. The other data values are plotted in active continental margin but could not show on the negative side of the vertical logarithmic scale (Figure 4).

\subsection{Provenance or Source Rock Determination Using Major} Oxides. Discrimination diagram proposed by Roser and Korsch [9] distinguish the sources of the sediments into four provenance zones, mafic, intermediate, felsic, igneous provenances (Figure 5). The analysis was based on the chemical analyses in which $\mathrm{Al}_{2} \mathrm{O}_{3} / \mathrm{SiO}_{2}, \mathrm{~K}_{2} \mathrm{O} / \mathrm{Na}_{2} \mathrm{O}$, and $\mathrm{Fe}_{2} \mathrm{O}_{3}+\mathrm{MgO}$ proved the most valuable discriminant. The plot of the two discriminant functions is based upon the oxides of $\mathrm{Ti}, \mathrm{Al}$, $\mathrm{Fe}, \mathrm{Mg}, \mathrm{Ca}, \mathrm{Na}$, and $\mathrm{K}$ and most effectively differentiates between the provenances in Figure 5. The plot is based on the discriminant functions 1 and 2 which are ratio for raw plots. The plots using the raw oxides (Figure 5) revealed that the sediments in the well were sourced from felsic and very little from quartzoze sedimentary provenances. The problem of biogenic $\mathrm{CaO}$ in $\mathrm{CaCO}_{3}$ and also biogenic $\mathrm{SiO}_{2}$ is circumvented by using ratio plots in which the discriminant functions are based upon the ratios of $\mathrm{TiO}_{2}, \mathrm{Fe}_{2} \mathrm{O}, \mathrm{MgO}$, $\mathrm{Na}_{2} \mathrm{O}$, and $\mathrm{K}_{2} \mathrm{O}$ all to $\mathrm{Al}_{2} \mathrm{O}$. The formula for the raw oxides used in Figure 5 is given as

discriminant function 1: $-1.773 \mathrm{TiO}_{2}+0.607 \mathrm{Al}_{2} \mathrm{O}_{3}+$ $0.76 \mathrm{Fe}_{2} \mathrm{O}_{3 \text { (total) }}-1.5 \mathrm{MgO}+0.616 \mathrm{CaO}+0.509 \mathrm{Na}_{2} \mathrm{O}-$ $1.224 \mathrm{~K}_{2} \mathrm{O}-9.09$;

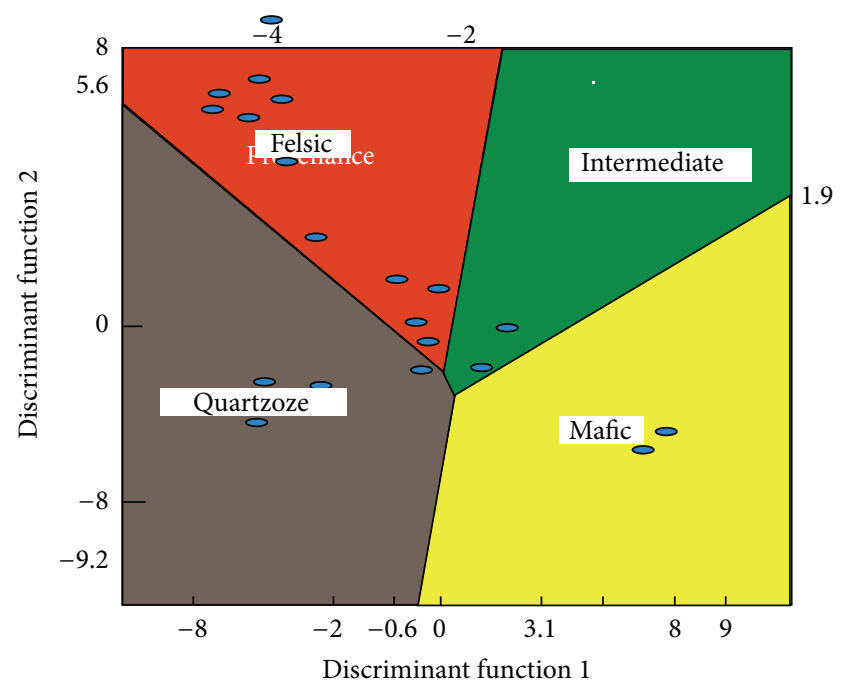

FIGURE 5: Discriminant function diagram for the provenance signatures of sandstone mudstone suites using major elements after Roser and Korsch [9]. The fields were dominantly mafic, intermediate, and felsic igneous provenances. Also shown is the field with quartzoze sedimentary provenance.

discriminant function 2: $0.445 \mathrm{TiO}_{2}+0.7 \mathrm{Al}_{2} \mathrm{O}_{3}-$ $0.25 \mathrm{Fe}_{2} \mathrm{O}_{3 \text { (total) }}-1.142 \mathrm{MgO}+0.438 \mathrm{CaO}+$ $1.475 \mathrm{Na}_{2} \mathrm{O}+1.426 \mathrm{~K}_{2} \mathrm{O}-6.861$.

Also the discrimination diagram for detrital grains after Grigsby [10] using detrital grains as a provenance indicator is shown in Figure 6. Grigsby proposed that the provenance source for sedimentary grains can be determined by the plot in Figure 6.

The trace element oxide distributions as plotted in Figure 7 generally show positive correlation with $\mathrm{Al}_{2} \mathrm{O}_{3}$, reflecting association of most elements with the clay fraction. $\mathrm{SiO}_{2}$ content has a strong negative correlation with $\mathrm{Al}_{2} \mathrm{O}_{3}$ reflecting that much of $\mathrm{SiO}_{2}$ is present as quartz grains. It also confirms the quartz enrichment in the sand fraction. With the exception of $\mathrm{SiO}_{2}, \mathrm{Na}_{2} \mathrm{O}$, and $\mathrm{CaO}$, the other oxides broadly follow the trend of positive correlation with (increasing as $\mathrm{Al}_{2} \mathrm{O}_{3}$ increases) indicating that they are associated with micaceous and/or clay minerals in the sediments. Plotting graphs of major oxides versus $\mathrm{Al}_{2} \mathrm{O}_{3}$ (Figure 7) variation diagrams, $\mathrm{Fe}_{2} \mathrm{O}_{3}, \mathrm{MnO}_{2}, \mathrm{MgO}, \mathrm{TiO}_{2}, \mathrm{FeO}, \mathrm{P}_{2} \mathrm{O}_{5}$, and $\mathrm{K}_{2} \mathrm{O}$, show positive correlation.

The observed depletion in $\mathrm{Na}_{2} \mathrm{O}$ and $\mathrm{CaO}$ (negative correlation) indicates that the studied sediments have suffered from weathering and recycling $[11,12]$. Generally, $\mathrm{Ca}, \mathrm{Na}$, and $\mathrm{K}$ contents are controlled by feldspars and thus strong depletion in $\mathrm{CaO}$ and $\mathrm{Na}_{2} \mathrm{O}$ further suggests destruction of plagioclase due to chemical weathering in the source or during transport (Table 2).

3.4. Trace Elements. Discrimination diagram to describe source rock composition is the $\mathrm{Zr} / \mathrm{Ti}-\mathrm{Nb} / \mathrm{Y}$ discrimination diagram after Winchester and Floyd [13] and the Th/Sc-Z/Sc diagram after McLennan et al. [14]. 
TABLe 2: Th/Sc-Zr-Sc, La, Co, Th, and Sc values.

\begin{tabular}{|c|c|c|c|c|c|c|c|c|}
\hline Samples depth & Lithology & $\mathrm{Th} / \mathrm{Sc}$ & $\mathrm{Zr} / \mathrm{Sc}$ & $\mathrm{La}$ & Co & Th & $\mathrm{Sc}$ & $\mathrm{Zr} / 10$ \\
\hline $1160-1180$ & Sand & 2.8 & 36.6 & 8.9 & 1.9 & 3.4 & 1.2 & 4.39 \\
\hline $1560-1580$ & Sand & 2.4 & 29.5 & 8.1 & 1.4 & 2.6 & 1.1 & 3.24 \\
\hline 1960-1980 & Sand & 2.0 & 27.5 & 9.2 & 3.9 & 3.2 & 1.6 & 4.4 \\
\hline $2960-2980$ & Shale & 1.7 & 28.3 & 16.7 & 13 & 5.5 & 3.2 & 9.04 \\
\hline $3960-3980$ & Shale & 1.4 & 23.0 & 30.1 & 13.2 & 9.9 & 7.1 & 16.3 \\
\hline $4560-4580$ & Shale & 1.2 & 17.2 & 31.7 & 12.9 & 10.4 & 8.6 & 14.8 \\
\hline $5460-5480$ & Shale & 1.5 & 37.3 & 9.1 & 9 & 3.8 & 2.5 & 9.33 \\
\hline $5760-5780$ & Shale & 1.3 & 40.1 & 9.6 & 17.4 & 5.8 & 4.4 & 17.65 \\
\hline $6160-6180$ & Shale & 0.9 & 20.6 & 23.2 & 9.7 & 6.8 & 7.5 & 15.48 \\
\hline $7060-7080$ & Sand & 1.4 & 40.9 & 8.9 & 11.7 & 2.6 & 1.9 & 7.78 \\
\hline $7260-7280$ & Sand & 0.6 & 37.3 & 4.6 & 12 & 1.7 & 2.7 & 10.07 \\
\hline $7560-7580$ & Sand & 0.7 & 27.0 & 6.4 & 19.2 & 2.2 & 3.1 & 8.36 \\
\hline $7760-7780$ & Shale & 1.3 & 23.6 & 16.1 & 13.2 & 6.6 & 4.9 & 11.56 \\
\hline $7960-7980$ & Shale & 0.8 & 26.3 & 5.9 & 29.4 & 2.2 & 2.9 & 7.63 \\
\hline $8060-8080$ & Shale & 1.9 & 38.3 & 8.1 & 11.5 & 3.4 & 1.8 & 6.9 \\
\hline $8160-8180$ & Sand & 2.2 & 36.3 & 17.9 & 12.4 & 6.4 & 2.9 & 10.52 \\
\hline $8560-8580$ & Sand & 1.5 & 21.5 & 11.5 & 41.4 & 3.8 & 2.5 & 5.38 \\
\hline $8960-8980$ & Shale & 1.6 & 24.8 & 26 & 8.5 & 10 & 6.3 & 15.6 \\
\hline $10,360-10,380$ & Shale & 2.5 & 37.5 & 18.6 & 11.4 & 6.6 & 2.6 & 9.76 \\
\hline $11,060-11,080$ & Shale & 1.1 & 19.6 & 37.6 & 21.4 & 10.1 & 9.3 & 18.23 \\
\hline $11,460-11,480$ & Shale & 0.8 & 17.5 & 29.2 & 22.4 & 9 & 10.9 & 19.08 \\
\hline
\end{tabular}

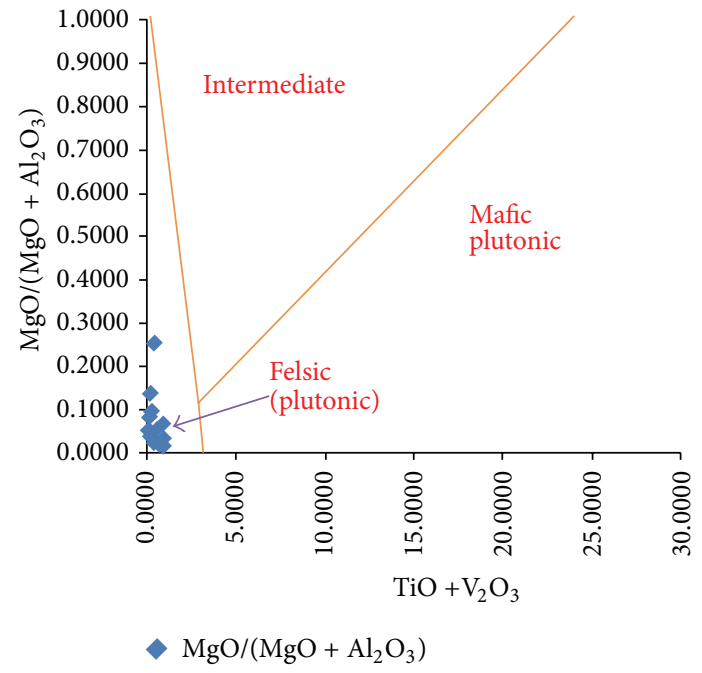

FIgure 6: Discrimination plot of $\mathrm{TiO}_{2}+\mathrm{V}_{2} \mathrm{O}_{3}$ versus $\mathrm{MgO} /(\mathrm{MgO}+$ $\mathrm{Al}_{2} \mathrm{O}_{3}$ ) for detrital grains after Grigsby [10].

Floyd and Winchester, in a series of papers (e.g., $[13,16-$ 18]), specifically addressed the identification of rock type. The most commonly used approach is their $\mathrm{Zr} / \mathrm{TiO}_{2}-\mathrm{Nb} / \mathrm{Y}$ diagram [13], which has subsequently been updated using a much larger dataset and statistically drawn boundaries by Pearce [19]. This diagram is essentially a proxy for the TAS classification diagram, where $\mathrm{Nb} / \mathrm{Y}$ is a proxy for alkalinity $\left(\mathrm{Na}_{2} \mathrm{O}+\mathrm{K}_{2} \mathrm{O}\right)$ and $\mathrm{Zr} / \mathrm{TiO}_{2}$ is a proxy for silica. $\mathrm{Nb} / \mathrm{Y}$ increases from subalkalic to alkalic compositions and $\mathrm{Zr} / \mathrm{TiO}_{2}$ increases from basic to acid compositions.

$\mathrm{Th} / \mathrm{Sc}-\mathrm{Z} / \mathrm{Sc}$ diagram after McLennan et al. [14] plot gives insight in the degree of fractionation of the source rocks which is expressed in Th/Sc ratio. Furthermore, this plot describes the degree of sediment recycling that is expressed in the $\mathrm{Zr} / \mathrm{Sc}$ ratio. Increased recycling concentrates zircon in sedimentary rocks (increase in $\mathrm{Zr}$ concentration) at the expense of volcanic material contained in the detritus (decrease in Sc-concentrations). The plot of $\mathrm{Th} / \mathrm{Sc}$ versus $\mathrm{Zr} / \mathrm{Sc}$ diagram is shown in Figure 8, describing most of the sediments found in the zone of recycling and zircon concentration of upper continental crust.

Trace elements such as $\mathrm{La}, \mathrm{Th}, \mathrm{Zr}, \mathrm{Nb}, \mathrm{Y}, \mathrm{Sc}, \mathrm{Co}$, and $\mathrm{Ti}$ have been recognized as valuable provenance signatures for shales, arenites, and wackes $[15,20,21]$. Bivariate plots of $\mathrm{Ti} / \mathrm{Zr}-\mathrm{La} / \mathrm{Sc}$ as well as triangular $\mathrm{La}-\mathrm{Th}-\mathrm{Sc}, \mathrm{Th}-\mathrm{Sc}-\mathrm{Zr} / 10$, Th-Sc-Zr/10, and Th-Co-Zr/10 plots are useful means to discriminate the tectonic settings of clastic sedimentary rocks [15].

Distinctive fields for four environments are recognized on the trivariate plots of $\mathrm{La}-\mathrm{Th}-\mathrm{Sc}, \mathrm{Th}-\mathrm{Sc}-\mathrm{Zr} / 10$, and $\mathrm{Th}$ $\mathrm{Co}-\mathrm{Zr} / 10$. On La-Th-Sc plot, the fields of active continental margin sediments and passive continental margin sediments 
Titanium oxide $\mathrm{TiO}_{2}$
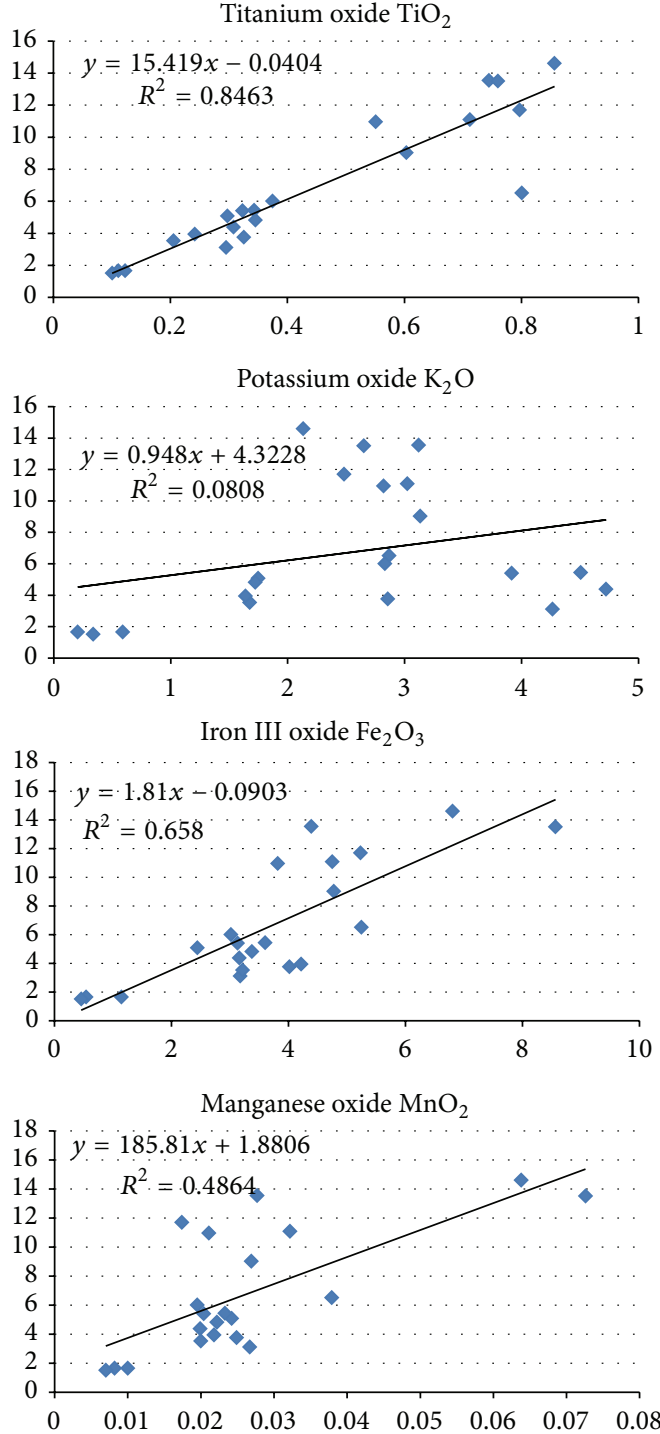

Calcium oxide $\mathrm{CaO}$

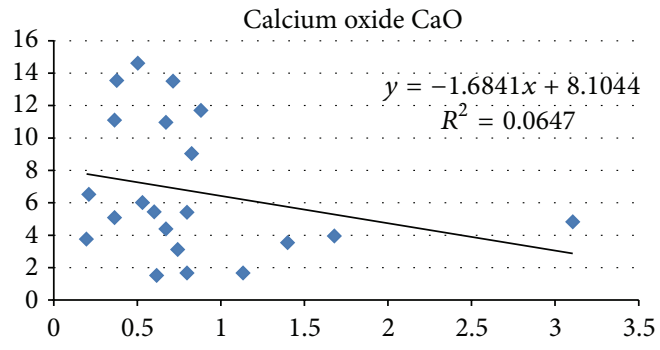

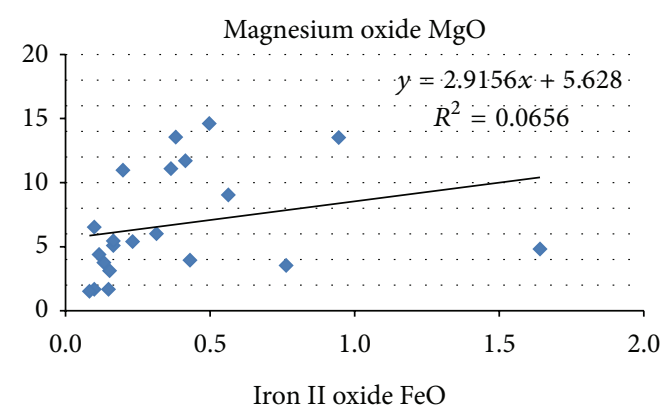
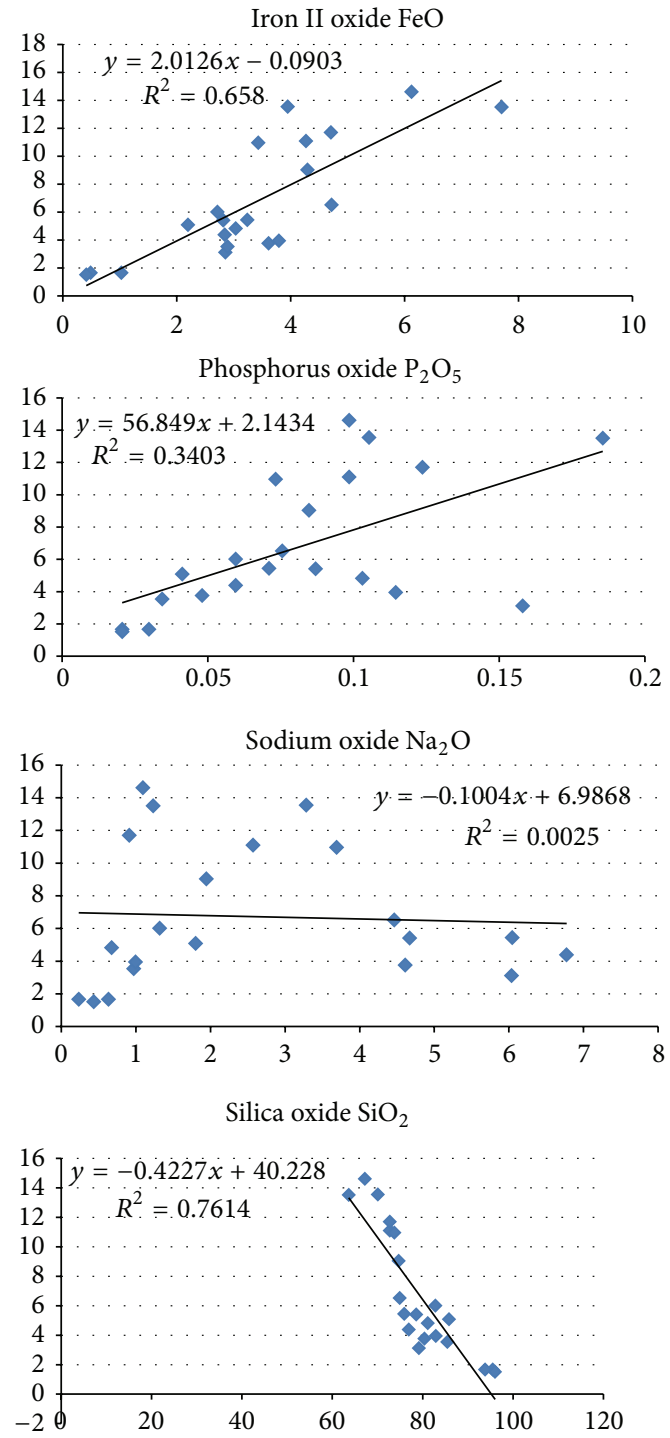

FIgURE 7: Covariation of $\mathrm{Al}_{2} \mathrm{O}_{3}$ versus major elements for the 11 major oxides. There is a positive correlation of $\mathrm{Al}_{2} \mathrm{O}_{3}$ with almost all the major elements; $\mathrm{SiO}_{2}$ shows negative correlation.

overlap, but the $\mathrm{Th}-\mathrm{Sc}-\mathrm{Zr} / 10$ and $\mathrm{Th}-\mathrm{Co}-\mathrm{Zr} / 10$ show complete separation:

La-Th-Sc discrimination diagram for greywackes in Figure 9;

Th-Sc-Zr/10 discrimination diagrams for greywackes in Figure 10;
Th-Co- $\mathrm{Zr} / 10$ discrimination diagrams for greywackes in Figure 11 (after [15]).

Also the various plots that indicate the felsic provenance of the samples are as shown in Figures 12 and 13 (Table 4).

3.5. Various Trace Elemental Ratios Used in Evaluating Provenance and Depositional Conditions. Elevated values of 


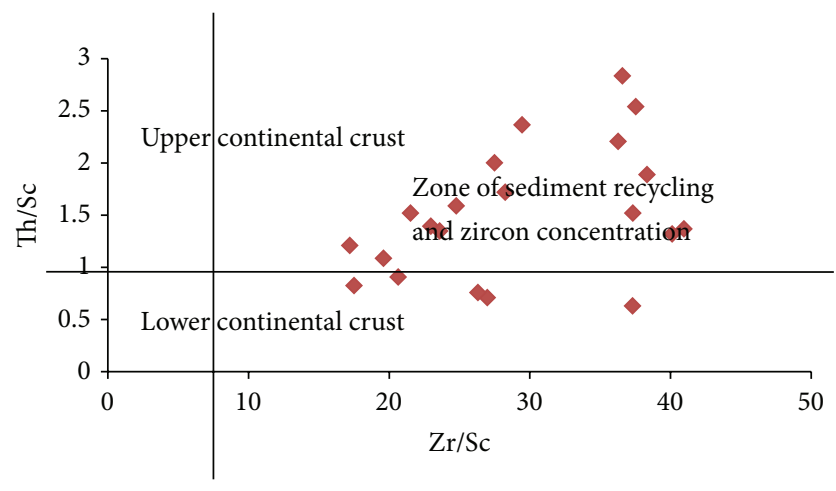

Figure 8: Th/Sc versus $\mathrm{Zr} / \mathrm{Sc}$ diagram after McLennan et al. [14], reflecting reworking and upper crust input.

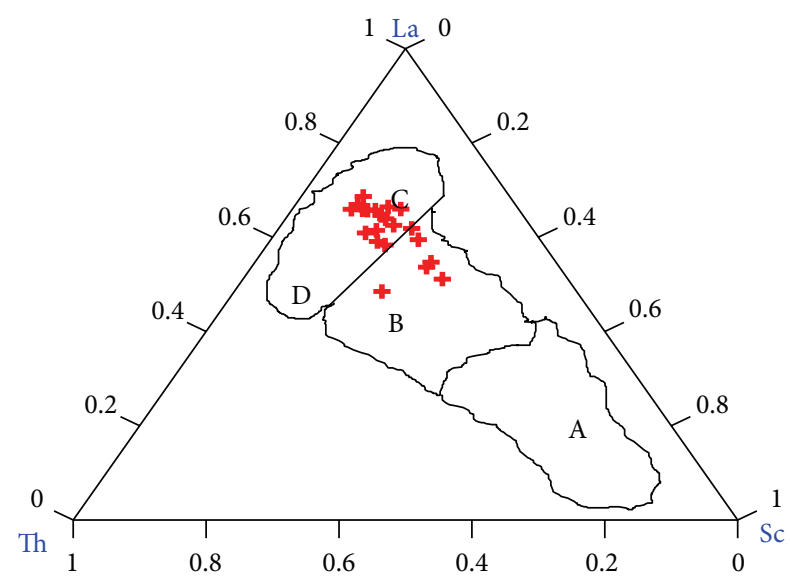

FIgure 9: The plot of La-Th-Sc showing the provenance of the sediments to be mainly of active continental margin (after [15]). The fields are A: oceanic island arc, B: continental island arc, C: active continental margin, and D: passive margin.

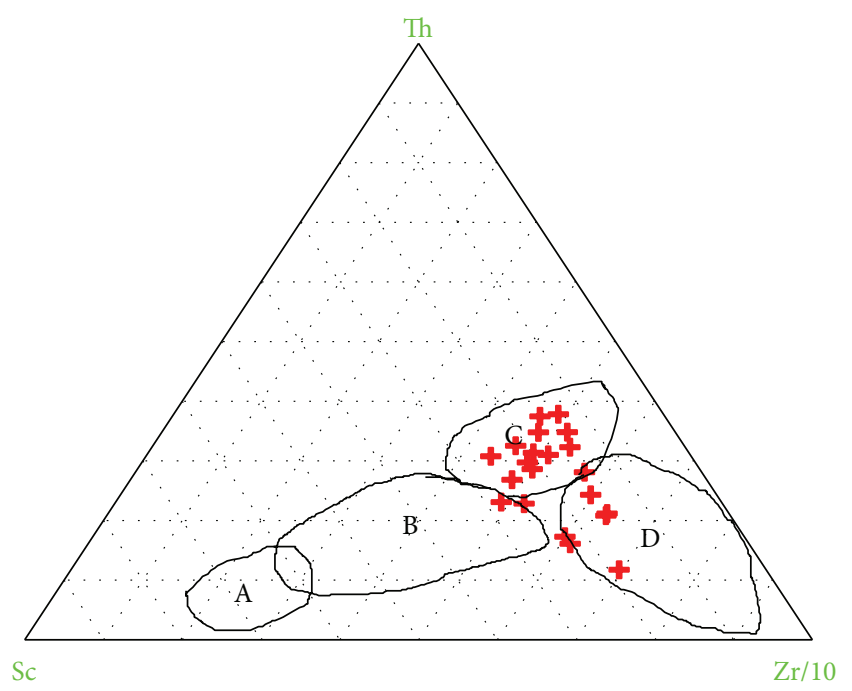

FIGURE 10: Th-Sc-Zr/10 plot showing the provenance of the sediments to be still mainly of active continental margin (after [15]).

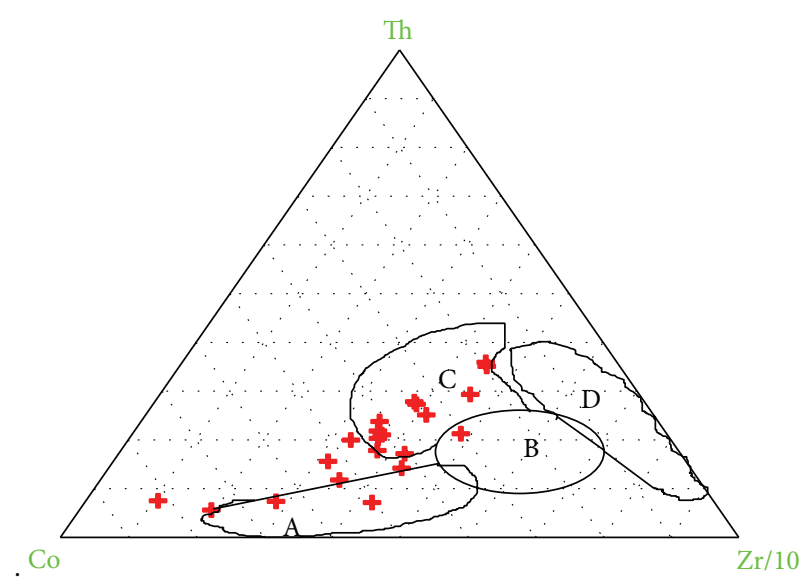

FIgURE 11: Th-Co-Zr/10 plot showing the provenance of the sediments to be active continental margin (after [15]).

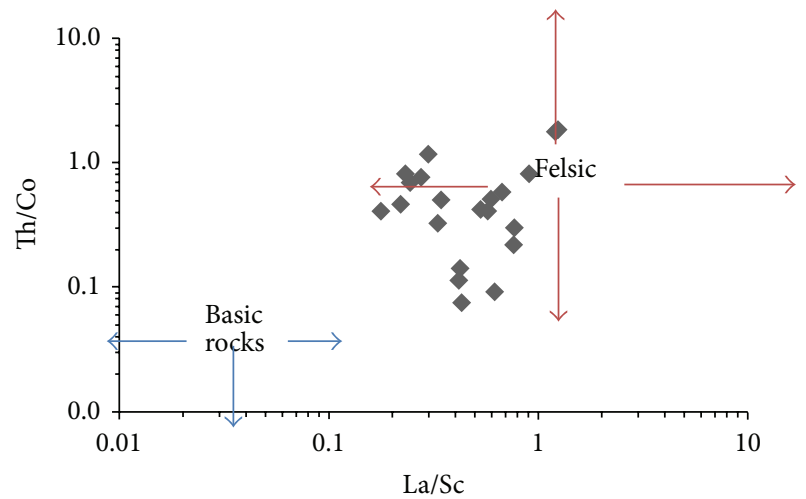

FIGURE 12: Th/Co versus La/Sc for the samples. The logarithmic plot shows that the samples are sourced from felsic or acidic silicic rocks, and very few of the samples tend towards intermediate provenance.

thorium with respect to uranium can indicate a felsic source. The $\mathrm{Th} / \mathrm{U}$ ratio, which is often used in relation to Th- and $\mathrm{U}$-concentrations as present in weathering under oxidizing conditions, has been used to determine felsic provenance $[14,22]$. Weathering under oxidizing conditions results in the mobilization of uranium as $\mathrm{U}^{6+}$, whereas thorium (Th) remains immobile. This causes the $\mathrm{Th} / \mathrm{U}$ ratio to increase significantly. Higher abundances of incompatible elements like Th indicate felsic rather than mafic sources. Materials such as granodiorite source from old upper continental crust and from felsic gneisses are good examples. The $\mathrm{Th} / \mathrm{U}$ ratio can only be used for sedimentary rocks. The Th/U ratio has an average of 4.1 (Table 3 ) which is very close to that of upper continental crust of 3.8. The high ratios of Th/Sc and $\mathrm{Zr} / \mathrm{Sc}$ indicate a slight input of felsic materials from recycled sedimentary provenance.

$\mathrm{Al}_{2} \mathrm{O}_{3} / \mathrm{TiO}_{2}$ ratios of most clastic rocks are essentially used to infer the source rock compositions, because ratio $\mathrm{Al}_{2} \mathrm{O}_{3} / \mathrm{TiO}_{2}$ increases from 3 to 8 for mafic igneous rocks, from 8 to 21 for intermediate rocks, and from 15 to 70 for felsic igneous rocks [27]. It will be observed that almost all values 
TABLE 3: Table of various elemental ratios.

\begin{tabular}{|c|c|c|c|c|c|c|c|c|}
\hline Sample (in meters) & Lithology & K/Cs ratio & Th/U ratio & $\mathrm{Cr} / \mathrm{Th}$ & Th/Co & $\mathrm{Al}_{2} \mathrm{O}_{3} / \mathrm{SiO}_{2}$ & $\mathrm{La} / \mathrm{Sc}$ & $\mathrm{Th} / \mathrm{Sc}$ \\
\hline $1160-1180$ & Sand & 0.2 & 4.9 & 2.9 & 1.8 & 17 & 7.42 & 2.83 \\
\hline $1560-1580$ & Sand & 0.3 & 4.3 & 2.7 & 1.9 & 15 & 7.36 & 2.36 \\
\hline 1960-1980 & Sand & 0.4 & 4.0 & 3.8 & 0.8 & 17 & 5.75 & 2.00 \\
\hline $2960-2980$ & Shale & 1.1 & 3.4 & 6.5 & 0.4 & 17 & 5.22 & 1.72 \\
\hline $3960-3980$ & Shale & 1.1 & 3.5 & 7.1 & 0.8 & 16 & 4.24 & 1.39 \\
\hline $4560-4580$ & Shale & 1.0 & 3.7 & 7.7 & 0.8 & 19 & 3.69 & 1.21 \\
\hline $5460-5480$ & Shale & 2.0 & 4.8 & 16.6 & 0.4 & 13 & 3.64 & 1.52 \\
\hline $5760-5780$ & Shale & 1.3 & 4.8 & 14.1 & 0.3 & 8 & 2.18 & 1.32 \\
\hline $6160-6180$ & Shale & 0.9 & 4.0 & 9.9 & 0.7 & 18 & 3.09 & 0.91 \\
\hline $7060-7080$ & Sand & 3.2 & 5.2 & 23.5 & 0.2 & 10 & 4.68 & 1.37 \\
\hline $7260-7280$ & Sand & 3.3 & 1.5 & 55.3 & 0.1 & 15 & 1.70 & 0.63 \\
\hline $7560-7580$ & Sand & 2.9 & 2.8 & 56.8 & 0.1 & 18 & 2.06 & 0.71 \\
\hline 7760-7780 & Shale & 2.0 & 4.1 & 8.6 & 0.5 & 15 & 3.29 & 1.35 \\
\hline $7960-7980$ & Shale & 3.3 & 3.1 & 75.5 & 0.1 & 18 & 2.03 & 0.76 \\
\hline $8060-8080$ & Shale & 1.4 & 3.1 & 12.1 & 0.3 & 18 & 4.50 & 1.89 \\
\hline $8160-8180$ & Sand & 1.6 & 4.3 & 8.0 & 0.5 & 16 & 6.17 & 2.21 \\
\hline $8560-8580$ & Sand & 2.3 & 4.8 & 51.8 & 0.1 & 20 & 4.60 & 1.52 \\
\hline $8960-8980$ & Shale & 1.9 & 4.3 & 9.4 & 1.2 & 15 & 4.13 & 1.59 \\
\hline $10,360-10,380$ & Shale & 3.4 & 6.0 & 7.0 & 0.6 & 15 & 7.15 & 2.54 \\
\hline $11,060-11,080$ & Shale & 1.1 & 5.3 & 9.2 & 0.5 & 17 & 4.04 & 1.09 \\
\hline $11,460-11,480$ & Shale & 0.8 & 4.7 & 10.7 & 0.4 & 16 & 2.68 & 0.83 \\
\hline Average & & 1.7 & 4.1 & 19.0 & 73.7 & 15.9 & & \\
\hline
\end{tabular}

TABLE 4: Range of elemental ratios for felsic and mafic igneous rocks and corresponding upper continental crust values. The table of range of mafic and felsic rocks is after Cullers [23, 24]; Cullers and Podkovyrov [25]; Cullers et al. [26]; and the UCC values are after Taylor and McLennan [20].

\begin{tabular}{lccc}
\hline $\begin{array}{l}\text { Elemental } \\
\text { ratios }\end{array}$ & Felsic rocks & Mafic rocks & $\begin{array}{c}\text { Upper continental } \\
\text { crust }\end{array}$ \\
\hline $\mathrm{Th} / \mathrm{Sc}$ & $0.84-20.05$ & $0.05-0.22$ & 0.79 \\
$\mathrm{Th} / \mathrm{Co}$ & $0.27-19.4$ & $0.04-1.4$ & 0.63 \\
$\mathrm{Th} / \mathrm{Cr}$ & $0.13-2.7$ & $0.018-0.046$ & 0.13 \\
$\mathrm{Cr} / \mathrm{Th}$ & $4.00-15.00$ & $25-500$ & 7.76 \\
$\mathrm{La} / \mathrm{Th}$ & $25.0-16.3$ & $0.43-0.86$ & 2.21 \\
\hline
\end{tabular}

for the $\mathrm{Al}_{2} \mathrm{O}_{3} / \mathrm{TiO}_{2}$ ratio are above 15 with an average of 15.9 (Table 3) which is an indication that the source rock is felsic or acidic igneous rock such as granite, granodiorite, rhyolite, dacite, or aplite. The elevated $\mathrm{Zr} / \mathrm{Sc}$ ratios reflect significant reworking and a clear input from upper crust igneous sources. Th/Sc values for the analyzed samples (Table 3 ) were in the range of $0.83-2.83$, implying a felsic igneous provenance. The same applies for the Th/Co ratio (Table 3) as most of the values are above 0.27 and less than 19.5. However it will be observed that 7060-7080, 7260-7280, 7560-7580, and 79607980; their Th/Co ratio is less than 0.22 (implying mafic source) and their $\mathrm{Cr} / \mathrm{Th}$ ratios are greater than 15.00 , around 50, and even 75.5 for 7960-7980 and this also implies a mafic source input.

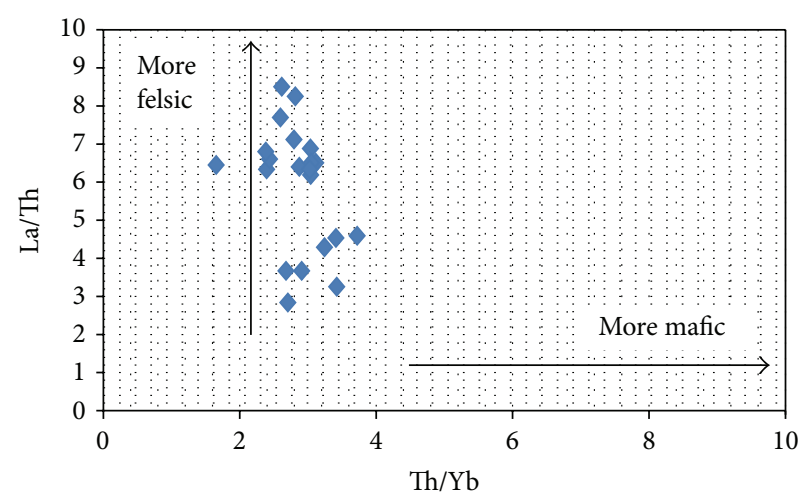

Figure 13: La/Th versus Th/Yb plot showing felsic versus mafic character after McLennan et al., [20].

The La/Th versus Th/Yb plots have been used to differentiate between felsic and mafic nature of source rocks [15, 28]. In these plots Figure 13, the studied samples show felsic character of source rocks by its unusually high La/Th (felsic provenance) as compared with $\mathrm{Th} / \mathrm{Yb}$ (mafic provenance).

3.6. Provenance from Rare Earth Elements. Rare earth elements (shown in Table 5) comprise the lanthanide elements [La-Lu] as well as Y [29]. Since Y mirrors the heavy lanthanides Dy-Ho in terms of geochemical behavior, it is typically included with them for discussion. Sc may also be included because, in low temperature aqueous fluids such as seawater, it behaves similarly to REE in having exceptionally 
TABLE 5: Rare earth elements concentrations in ppm for the analyzed samples.

\begin{tabular}{|c|c|c|c|c|c|c|c|c|c|c|c|c|c|c|c|}
\hline Sample (in meters) & $\begin{array}{c}\mathrm{La} \\
\mathrm{ppm}\end{array}$ & $\begin{array}{c}\mathrm{Ce} \\
\mathrm{ppm}\end{array}$ & $\begin{array}{c}\mathrm{Pr} \\
\mathrm{ppm}\end{array}$ & $\begin{array}{c}\mathrm{Nd} \\
\mathrm{ppm}\end{array}$ & $\begin{array}{c}\mathrm{Sm} \\
\mathrm{ppm}\end{array}$ & $\begin{array}{c}\mathrm{Eu} \\
\mathrm{ppm}\end{array}$ & $\begin{array}{c}\mathrm{Gd} \\
\mathrm{ppm}\end{array}$ & $\begin{array}{c}\mathrm{Tb} \\
\mathrm{ppm}\end{array}$ & $\begin{array}{c}\text { Dy } \\
\text { ppm }\end{array}$ & $\begin{array}{c}\text { Ho } \\
\mathrm{ppm}\end{array}$ & $\begin{array}{c}\text { Er } \\
\mathrm{ppm}\end{array}$ & $\begin{array}{c}\mathrm{Tm} \\
\mathrm{Ppm}\end{array}$ & $\begin{array}{c}\mathrm{Yb} \\
\mathrm{ppm}\end{array}$ & $\begin{array}{c}\mathrm{Lu} \\
\mathrm{ppm}\end{array}$ & $\begin{array}{c}\mathrm{Y} \\
\mathrm{ppm}\end{array}$ \\
\hline $1160-1180$ & 8.9 & 20.01 & 2 & 8.9 & 1.5 & 0.1 & 1.2 & 0.1 & 1 & 0.1 & 0.4 & $<0.1$ & 0.4 & $<0.1$ & 3.3 \\
\hline $1560-1580$ & 8.1 & 18.11 & 1.9 & 8 & 1.3 & $<0.1$ & 1 & 0.1 & 0.8 & 0.1 & 0.3 & $<0.1$ & 0.4 & $<0.1$ & 2.8 \\
\hline 1960-1980 & 9.2 & 19.38 & 2.1 & 9.6 & 1.6 & 0.2 & 1.4 & 0.1 & 1.1 & 0.2 & 0.5 & $<0.1$ & 0.5 & $<0.1$ & 4.6 \\
\hline $2960-2980$ & 16.7 & 36.08 & 3.9 & 16.9 & 2.8 & 0.4 & 2.2 & 0.3 & 1.8 & 0.3 & 0.7 & 0.1 & 0.8 & 0.1 & 7.1 \\
\hline $3960-3980$ & 30.1 & 68.14 & 7.6 & 35.3 & 5.7 & 1 & 4.4 & 0.6 & 3.5 & 0.6 & 1.6 & 0.2 & 1.6 & 0.2 & 14.7 \\
\hline $4560-4580$ & 31.7 & 67.95 & 7.6 & 33.7 & 5.2 & 0.9 & 4.8 & 0.6 & 3.5 & 0.6 & 1.7 & 0.2 & 1.6 & 0.2 & 14.2 \\
\hline $5460-5480$ & 9.1 & 21.18 & 2.6 & 12.4 & 1.9 & 0.3 & 1.7 & 0.2 & 1.2 & 0.2 & 0.5 & $<0.1$ & 0.6 & $<0.1$ & 4.9 \\
\hline $5760-5780$ & 9.6 & 25.82 & 3.1 & 14.7 & 2.8 & 0.5 & 2.5 & 0.3 & 1.9 & 0.3 & 0.8 & 0.1 & 0.9 & 0.1 & 5.7 \\
\hline $6160-6180$ & 23.2 & 58.84 & 7.3 & 34.8 & 5.8 & 1.1 & 4.9 & 0.6 & 3.8 & 0.6 & 1.4 & 0.2 & 1.5 & 0.2 & 14.9 \\
\hline $7060-7080$ & 8.9 & 24.9 & 3.4 & 15.5 & 2.6 & 0.5 & 2.7 & 0.3 & 1.8 & 0.3 & 0.7 & $<0.1$ & 0.8 & $<0.1$ & 8.5 \\
\hline $7260-7280$ & 4.6 & 15.37 & 2.2 & 11 & 1.8 & 0.3 & 1.6 & 0.2 & 1.3 & 0.2 & 0.6 & $<0.1$ & 0.6 & $<0.1$ & 5.4 \\
\hline $7560-7580$ & 6.4 & 19.4 & 2.6 & 13.7 & 2.3 & 0.5 & 2.3 & 0.3 & 1.6 & 0.3 & 0.7 & $<0.1$ & 0.6 & $<0.1$ & 6 \\
\hline $7760-7780$ & 16.1 & 45.68 & 6 & 27.7 & 4.5 & 0.8 & 3.4 & 0.4 & 2.4 & 0.5 & 1 & 0.1 & 1 & 0.1 & 10.7 \\
\hline $7960-7980$ & 5.9 & 17.5 & 2.3 & 12.1 & 2.1 & 0.4 & 1.8 & 0.2 & 1.4 & 0.2 & 0.5 & $<0.1$ & 0.6 & $<0.1$ & 5.3 \\
\hline $8060-8080$ & 8.1 & 22.61 & 2.8 & 13.5 & 2.2 & 0.4 & 1.6 & 0.2 & 1.2 & 0.2 & 0.5 & $<0.1$ & 0.5 & $<0.1$ & 4.9 \\
\hline $8160-8180$ & 17.9 & 41.58 & 4.8 & 22.8 & 3.6 & 0.6 & 2.9 & 0.3 & 2.1 & 0.3 & 0.8 & 0.1 & 0.9 & 0.1 & 9 \\
\hline $8560-8580$ & 11.5 & 28.5 & 3.2 & 15.9 & 2.6 & 0.5 & 2 & 0.3 & 1.5 & 0.3 & 0.6 & $<0.1$ & 0.6 & $<0.1$ & 6.2 \\
\hline $8960-8980$ & 26 & 60.17 & 7.1 & 31.8 & 4.8 & 0.9 & 3.6 & 0.4 & 2.8 & 0.5 & 1.1 & 0.2 & 1.3 & 0.2 & 11.5 \\
\hline $10,360-10,380$ & 18.6 & 40.4 & 4.4 & 20.4 & 3 & 0.5 & 2.4 & 0.3 & 1.8 & 0.3 & 0.7 & 0.1 & 0.8 & 0.1 & 7.1 \\
\hline $11,060-11,080$ & 37.6 & 91.97 & 9.6 & 44.3 & 7.3 & 1.1 & 6.1 & 0.8 & 5 & 0.8 & 2.2 & 0.3 & 2.2 & 0.3 & 20.1 \\
\hline $11,460-11,480$ & 29.2 & 77.09 & 9.6 & 43.7 & 7.4 & 1.3 & 6.3 & 0.8 & 4.9 & 0.8 & 2 & 0.3 & 2.1 & 0.3 & 19.7 \\
\hline Average & 1.6 & 1.6 & 1.5 & 1.5 & 1.2 & VALUE! & 1.0 & 0.8 & 0.8 & 0.6 & 0.6 & 0.4 & 0.6 & & 0.9 \\
\hline
\end{tabular}

low concentrations and by entering the sixfold coordinated mineral sites. Low atomic number members of the series from La-Sm are termed the light rare earth elements (LREE). Those with higher atomic numbers from $\mathrm{Gd}-\mathrm{Yb}$ are termed the heavy rare earth elements (HREE).

The patterns of shapes and trending structure on REE diagrams can be used to evaluate the petrology of a rock. Most important is the Europium anomaly that at most times is enriched or depleted and as such assumes position which often lies off the general trend. This anomaly is defined by the other elements on the REE diagram and termed europium anomaly. If the plotted composition lies above the general trend, then the Eu anomaly is described as positive and if it lies below the general trend it is described as negative.

The REE pattern of average sediments is interpreted to reflect the average upper continental crust and thus a negative $\mathrm{Eu}$ anomaly is found in most sedimentary rocks. This indicates that shallow, intercrustal differentiation involving plagioclase differentiation (through either melting or fractional differentiation) must be a fundamental process in controlling the composition and element distribution within the continental crust [20]. Before the plot, the REE values in ppm as obtained from the analyzed samples have to be normalized. The REE chondrite normalizing factors used for this study are from Wakita et al. [30] as shown in Figure 14. Also the North American shale composition is used as shown in Figure 15. Besides the normalized plot, other parameters used to characterize the REE abundant in rocks include:

fractionation indices represented by $(\mathrm{La} / \mathrm{Yb})_{\mathrm{cn}}$ which is an index of the enrichment of the light rare earth elements (LREE) over heavy rare earth elements (HREE);

Eu anomaly;

Ce anomaly;

HREE depletion represented by $(\mathrm{Gd} / \mathrm{Yb})>2.0$; grain size.

3.7. Fractionating Indices/Degree of Fractionation of REE. The degree of fractionation of REE pattern can be expressed by concentration of light REE ( $\mathrm{La}$ or $\mathrm{Ce}$ ) ratio to the concentration of heavy REE (Yb). The lanthanum (La) and ytterbium $(\mathrm{Yb})$ are often used which will have to be normalized and this ratio is expressed as $\left(\mathrm{La}_{\mathrm{N}} / \mathrm{Yb}_{\mathrm{N}}\right)$. This combined with Eu anomaly is very important parameter that describes REE patterns and can be used in determining the source rock. These fractionation indices represented by $(\mathrm{La})_{\mathrm{N}} /(\mathrm{Yb})_{\mathrm{N}}$, that is, [(La sample/La chondrite)/(Yb sample/Yb chondrite)] ratio, can be used to define relative behavior of LREE to the HREE. This ratio has been calculated for all the samples in the present study as presented in Table 6 . It is within the range of 1.97 and 5.46 with an average value of 3.08 indicating that the HREE are very much depleted with respect to LREE in the present study. 


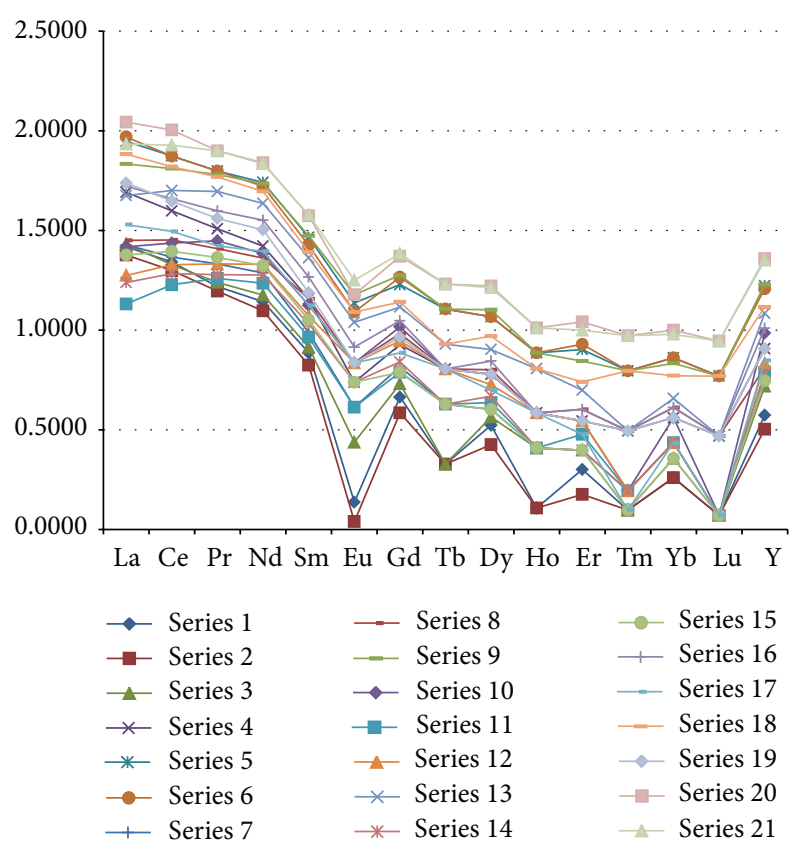

FIGURE 14: Wakita chondrite normalized spider diagrams.

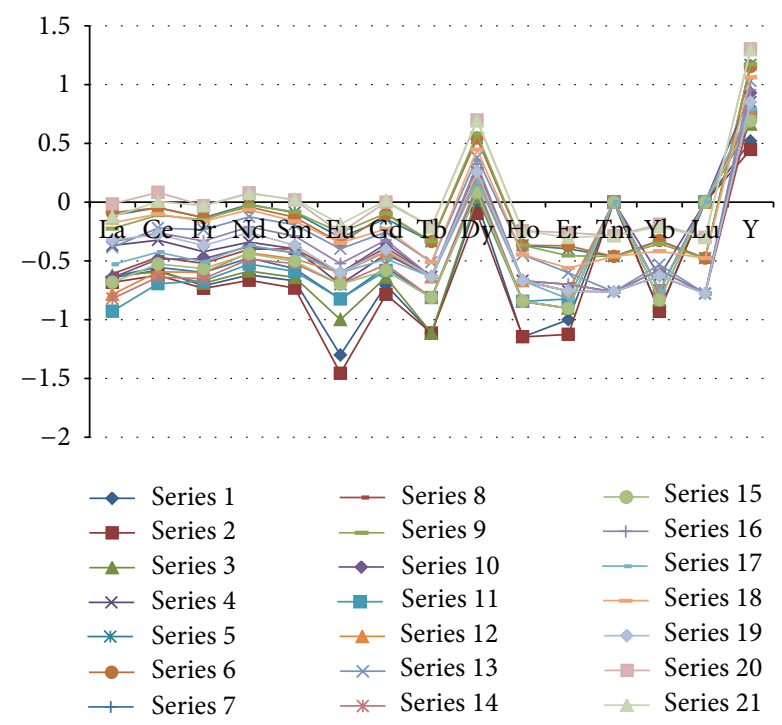

FIGURE 15: NASC normalized spider diagram.

3.7.1. Europium (Eu) and Cerium (Ce) Anomaly. Within rare earth elements under reducing conditions, as within the mantle or lower crust, europium may exist in the divalent state $\left(\mathrm{Eu}^{2+}\right)$. This results in an increase in the ionic radius of about $17 \%$ making it essentially identical to $\mathrm{Sr}^{2+}$. The consequence of this is that Eu substitutes freely in place of $\mathrm{Sr}$ in feldspars notably plagioclase feldspars, leading to distinctive geochemical behavior of "Eu" compared with other REE. In general, anomalous activity of $\mathrm{Eu}$ is an indication of an earlier event that occurred in a reducing igneous environment which eventually evolved into upper continental crust [20].
Similarly in oxidizing conditions, $\mathrm{Ce}^{3+}$ may be oxidized to $\mathrm{Ce}^{4+}$ leading to a decrease in the ionic radius of about $15 \%$. The only place where this reaction occurs on a large scale is marine environment associated with the formation of manganese nodules. When $\mathrm{Ce}^{3+}$ oxidizes to $\mathrm{Ce}^{4+}$, it separates as an insoluble phosphate if it is in a marine environment. This will cause a distinctive Ce depletion in ocean waters and phases precipitated in equilibrium with seawater. Apart from those anomalies, the REE behaves in an unusually coherent group of elements. There is a continuous decrease in ionic radii from La to Lu and this is termed lanthanide contraction. The decrease in ionic radii is due to increase in the effective nuclear charge pulling the electrons towards the nucleus thereby reducing the electron radii.

3.8. Eu Anomaly. Europium anomaly, usually represented by $\left[\mathrm{Eu} / \mathrm{Eu}^{*}\right]$, may be quantified by comparing the normalized measured Eu concentration with an expected concentration $\left(\mathrm{Eu}^{*}\right)$. The $\mathrm{Eu}^{*}$ is obtained by interpolating between the normalized values of Sm and Gd; that is, $\mathrm{Eu}^{*}=\left(\mathrm{Sm}_{\mathrm{n}}+\right.$ $\left.\mathrm{Gd}_{\mathrm{n}}\right) / 2$.

The Eu used in this study is the concentration of Eu in the sediments, that is, Wakita chondrite normalized, and $\mathrm{Eu}^{*}$ is a calculated value obtained by linear interpolation or average between $\mathrm{Sm}_{\mathrm{n}}$ (samarium chondrite normalized) and $\mathrm{Gd}_{\mathrm{n}}$ (gadolinium chondrite normalized). So the europium anomaly is given by

$$
\frac{\mathrm{Eu}}{\mathrm{Eu}^{*}}=\frac{\text { Average value of chondrite normalized } \mathrm{Eu} \text { of the data } \mathrm{Eu}_{\mathrm{n}}}{\text { Average value of chondrite normalized }\left(\mathrm{Sm}_{\mathrm{n}}+\mathrm{Gd}_{\mathrm{n}}\right) / 2} .
$$

Taylor and McLennan [20] recommended the use of a geometric mean for calculating the Eu anomaly as follows:

$$
\frac{\mathrm{Eu}}{\mathrm{Eu}^{*}}=\sqrt{\left\{\frac{\mathrm{Eu}_{\mathrm{n}}}{\mathrm{Sn}_{\mathrm{n}} \times \mathrm{Gd}_{\mathrm{n}}}\right\}} .
$$

Although a number of elements or minerals may determine the distribution of Eu during igneous processes, the most important is feldspar particularly plagioclase. Europium anomalies are majorly controlled by feldspars, particularly in felsic magmas. This is because $\mathrm{Eu}^{2+}$ (divalent form of $\mathrm{Eu})$ is present in plagioclase and potassium feldspars are compactable, in contrast with the incompatible trivalent REE. Thus the removal of feldspar from a felsic melt by crystal fractionation or partial melting of a rock in which feldspar is retained or present in the source will give rise to a negative $\mathrm{Eu}$ anomaly. In plagioclase, substantial $\mathrm{Eu}^{2+}$ may substitute for $\mathrm{Ca}^{2+}$ in place of $\mathrm{Sr}$; thus the Eu anomaly $\left(\mathrm{Eu} / \mathrm{Eu}^{*}\right)$ reflects the extent of plagioclase fractionation, leading to pronounced enrichments of its associated trivalent REE and depletion of Eu. Thus liquids that formed where plagioclase is a stable residual phase or from which plagioclase is crystallized and lost will tend to be significantly depleted in Eu so will have a negative $\mathrm{Eu}$ anomaly. On the other hand, Rudnick [31] suggested that the positive Eu anomaly is mainly due to the effect of areas prominent in hydrothermal vents or due to the feldspar origin. 
TABLE 6: REE chondrite normalized elemental ratios used in analyzing the provenance of the sediments.

\begin{tabular}{|c|c|c|c|c|c|c|c|c|c|c|c|}
\hline Samples & Lithology & $\mathrm{Eu} / \mathrm{Eu}^{*}$ & $\mathrm{La} / \mathrm{Yb}$ & $\mathrm{Ce} / \mathrm{Ce}^{*}$ & $\mathrm{Gd} / \mathrm{Yb}$ & $\mathrm{Zr} / \mathrm{TiO}_{2}$ & $\Sigma$ LREE & $\Sigma$ HREE & $\Sigma \mathrm{L} / \Sigma \mathrm{H}$ & $\mathrm{La} / \mathrm{Y}$ & $\mathrm{La} / \mathrm{V}$ \\
\hline $1160-1180$ & Sand & 0.48 & 5.46 & 1.02 & 2.56 & 0.04 & 6.0 & 2.2 & 2.8 & 2.70 & 2.70 \\
\hline $1560-1580$ & Sand & 0.00 & 5.30 & 1.03 & 2.25 & 0.03 & 5.8 & 1.9 & 3.1 & 2.89 & 0.74 \\
\hline 1960-1980 & Sand & 0.81 & 4.02 & 1.00 & 2.05 & 0.04 & 6.1 & 2.8 & 2.2 & 2.00 & 0.66 \\
\hline $2960-2980$ & Sand & 0.83 & 3.02 & 1.01 & 1.65 & 0.03 & 7.4 & 4.7 & 1.6 & 2.35 & 0.44 \\
\hline $3960-3980$ & Sand & 0.79 & 2.26 & 1.01 & 1.43 & 0.02 & 8.8 & 6.8 & 1.3 & 2.05 & 0.46 \\
\hline $4560-4580$ & Sand & 0.78 & 2.29 & 1.01 & 1.47 & 0.02 & 8.8 & 6.9 & 1.3 & 2.23 & 0.45 \\
\hline $5460-5480$ & Shale & 0.87 & 3.28 & 1.02 & 1.87 & 0.03 & 6.4 & 3.3 & 1.9 & 1.86 & 0.28 \\
\hline $5760-5780$ & Shale & 0.86 & 2.37 & 1.04 & 1.61 & 0.02 & 6.8 & 4.9 & 1.4 & 1.68 & 0.14 \\
\hline $6160-6180$ & Shale & 0.79 & 2.20 & 1.03 & 1.53 & 0.03 & 8.6 & 6.8 & 1.3 & 1.56 & 0.33 \\
\hline $7060-7080$ & Sand & 0.85 & 2.53 & 1.06 & 1.81 & 0.03 & 6.8 & 4.3 & 1.6 & 1.05 & 0.31 \\
\hline $7260-7280$ & Sand & 0.90 & 2.60 & 1.12 & 1.81 & 0.03 & 5.8 & 3.4 & 1.7 & 0.85 & 0.14 \\
\hline $7560-7580$ & Sand & 0.91 & 2.93 & 1.08 & 2.17 & 0.02 & 6.3 & 4.0 & 1.6 & 1.07 & 0.18 \\
\hline $7760-7780$ & Shale & 0.83 & 2.55 & 1.05 & 1.70 & 0.02 & 8.1 & 5.6 & 1.4 & 1.50 & 0.32 \\
\hline $7960-7980$ & Shale & 0.92 & 2.84 & 1.07 & 1.93 & 0.02 & 6.1 & 3.4 & 1.8 & 1.11 & 0.19 \\
\hline $8060-8080$ & Shale & 0.94 & 3.86 & 1.06 & 2.21 & 0.03 & 6.5 & 3.2 & 2.0 & 1.65 & 0.37 \\
\hline $8160-8180$ & Sand & 0.83 & 2.81 & 1.02 & 1.71 & 0.03 & 7.8 & 5.0 & 1.6 & 1.99 & 0.69 \\
\hline $8560-8580$ & Sand & 0.92 & 3.51 & 1.03 & 2.03 & 0.02 & 7.0 & 3.9 & 1.8 & 1.85 & 0.38 \\
\hline $8960-8980$ & Shale & 0.83 & 2.44 & 1.02 & 1.48 & 0.02 & 8.6 & 6.2 & 1.4 & 2.26 & 0.48 \\
\hline $10,360-10,380$ & Shale & 0.85 & 3.10 & 1.01 & 1.72 & 0.03 & 7.6 & 4.7 & 1.6 & 2.62 & 0.66 \\
\hline $11,060-11,080$ & Shale & 0.74 & 2.04 & 1.03 & 1.37 & 0.02 & 9.4 & 7.8 & 1.2 & 1.87 & 0.40 \\
\hline $11,460-11,480$ & Shale & 0.76 & 1.97 & 1.03 & 1.41 & 0.02 & 9.2 & 7.8 & 1.2 & 1.48 & 0.33 \\
\hline Average & & 0.79 & 3.02 & 1.04 & 1.80 & 0.03 & 7.33 & 4.74 & 1.70 & 1.81 & 0.41 \\
\hline
\end{tabular}

Values greater than 0.85 indicate positive Eu anomaly, values less than 0.85 indicate a negative Eu anomaly, and a value of precisely 0.85 indicates no anomaly. In the present study as illustrated in Table 6, Eu anomaly values vary from 0.00 to 0.92 with an average of 0.79 corresponding to negative Eu anomaly. This is also shown in Figures 14 and 15 as spider diagrams. Felsic rocks and sediments usually have negative anomalies due to lithospheric or intracrustal feldspar fractionation or breakdown of feldspars during weathering processes [32]. Felsic igneous rocks usually contain higher LREE/HREE ratios and more pronounced negative $\mathrm{Eu}$ anomalies, while mafic igneous rocks contain lower LREE/HREE ratios with few or no Eu anomalies [24]. In addition, Cullers [23] proposed that sediments with $\mathrm{Cr} / \mathrm{Th}$ ratios ranging from 2.5 to 19.5 and $\mathrm{Eu} / \mathrm{Eu}^{*}$ values from 0.48 to 0.78 come mainly from felsic not mafic sources. According to the study of McLennan et al. [21], active margin sediments, in contrast to passive margin sediments, often show lower $\mathrm{Eu} / \mathrm{Eu}^{*}$.

3.9. Ce Anomaly. $\mathrm{Ce} / \mathrm{Ce}^{*}$ anomaly is usually given by $\mathrm{Ce} / \mathrm{Ce}^{*}$ $=5 \times \mathrm{Ce}_{\mathrm{n} / 4\left\{\mathrm{La}_{\mathrm{n}}+\mathrm{Sm}_{\mathrm{n}}\right\}}$. The samples values (Table 6) range from 1.00 to 1.08 with calculated average value of 1.04 . This is no anomaly as it is approximately 1 . Ce anomaly $\left(\mathrm{Ce} / \mathrm{Ce}^{*}\right)$ can indicate REE redistribution during weathering possibly a consequence of fractionation also for $\mathrm{Sm}$ and $\mathrm{Nd}$ isotopes. Since the $\mathrm{Ce} / \mathrm{Ce}^{*}$ ratios are close to 1 , the small difference in $\mathrm{Ce} / \mathrm{Ce}^{*}$ for the studied rocks is within the uncertainties of the measurements. Thus no anomalous $\mathrm{Ce} / \mathrm{Ce}^{*}$ can be deduced.
3.10. $(\mathrm{Gd} / \mathrm{Yb})_{\mathrm{N}}$ Ratio. The $(\mathrm{Gd} / \mathrm{Yb})_{\mathrm{N}}$ ratio also documents the nature of source rocks and the composition of the continental crust [20]. Archean crust generally has higher $(\mathrm{Gd} / \mathrm{Yb})_{\mathrm{N}}$ ratio, recording typically values above 2.0 in sedimentary rocks, whereas the post-Archean rocks have $(\mathrm{Gd} / \mathrm{Yb})_{\mathrm{N}}$ values commonly between 1.0 and 2.0 [3335]. About four of the twenty-one analyzed samples have $(\mathrm{Gd} / \mathrm{Yb})_{\mathrm{N}}$ ratios greater than 2.0 (Table 6) indicating the possibility of the post-Archean rocks being the source rocks for the formation.

3.11. Grain Size and REE. REE in various grain sizes has been examined by Cullers et al. [36] and Cullers et al. [26]. They found that clay contains the largest fraction of REE (high $\mathrm{La} / \mathrm{Yb}$ ), followed by silt which is of lesser proportion/fraction and lowest fractions in sands (least $\mathrm{La} / \mathrm{Yb}$ ) than finer grain sizes. The presence and magnitude of $\mathrm{Eu}$ anomalies are however similar for all grain sizes. Because sandstones tend to have lower REE than shales, their REE patterns are more prone to be considerably dominated by heavy minerals.

\section{Conclusion}

4.1. Provenance of the Sediments. Based on major oxides most of the sample plots in the fields were felsic igneous provenances suggesting high content of silica from an acid rock most probably granite or gneiss or dacite or any acidic (felsic) igneous rock.

The provenance and prevalent conditions of deposition from various elemental ratios indicate that the $\mathrm{Th} / \mathrm{U}$ ratio 
has an average of 4.1 which is very close to that of upper continental crust of 3.8. The high ratios of $\mathrm{Th} / \mathrm{Sc}$ and $\mathrm{Zr} / \mathrm{Sc}$ indicate a slight input of felsic materials from recycled sedimentary provenance. Higher abundances of incompatible elements like Th indicate felsic rather than mafic sources. Elevated values of thorium with respect to uranium may imply a felsic source. It will be observed that most values for the $\mathrm{Al}_{2} \mathrm{O}_{3} / \mathrm{TiO}_{2}$ ratio fall between 15 and 70 (the range for igneous rock) which is an indication that the source rock is felsic or acidic igneous rock such as granite, granodiorite, rhyolite, dacite, or aplite. Th/Sc values for the analyzed samples were in the range of $0.83-2.83$, implying a felsic igneous provenance. The same applies for the Th/Co ratio as most of the values are above 0.27 and less than 19.5 (Th/Sc and $\mathrm{Th} / \mathrm{Co}$ values for felsic rocks are $0.84-20.05$ and 0.27 19.5, resp.). Thus the source of the rock weathered to give the sediment is a felsic or acidic igneous rock, probably granite. $\mathrm{Th} /$ Co versus $\mathrm{La} / \mathrm{Sc}$ logarithmic plot shows that the samples are sourced from felsic or acidic silicic rocks, and very few of the samples tend towards intermediate provenance.

Provenance from REE and negative EU anomaly points to the fact that average REE pattern of the sediments is interpreted to reflect the average upper continental crust. Coupled with a negative Eu anomaly, conclusions can be drawn that shallow, intercrustal differentiation involving plagioclase differentiation (through either melting or fractional differentiation) must be a fundamental process in removal of feldspar from a felsic melt. The LREE enrichment as well as relatively flat HREE pattern also confirms felsic source rock. The relative REE patterns and Eu anomaly size have also been utilized to deduce sources of sedimentary rocks $[20,37]$. Mafic rocks contain low LREE/HREE ratios and tend not to contain Eu anomalies, whereas more felsic rocks usually contain higher LREE/HREE ratios and negative Eu anomalies [38]. A negative Eu anomaly is a confirmation of the sediment's provenance from felsic sources. Thus from the enrichment LREE or higher LREE/HREE, we can conclude that the provenance of the sediments is felsic rock.

4.2. Tectonic Settings. From major oxides it can be concluded that the tectonic setting of the Niger delta is active continental margin and this confirms the cretaceous rift systems of West and Central Africa. The rift system extends for over $4000 \mathrm{~km}$ from Nigeria northwards into Niger and Libya and eastwards to Sudan and Kenya. This cretaceous rift system forms a trough in which those sediments are deposited. The trace elements confirmed the tectonic settings of the sediments as active continental margins. The trivariate plots of $\mathrm{La}-\mathrm{Th}-\mathrm{Sc}$, Th-Sc-Zr/10, and $\mathrm{Th}-\mathrm{Co}-\mathrm{Zr} / 10$ all register the provenance of the sediments to be active continental margin. The $\mathrm{Th} / \mathrm{Sc}$ versus $\mathrm{Zr} / \mathrm{Sc}$ diagram after McLennan et al. [14], confirms the zone of sediment recycling in upper crust input.

\section{Conflict of Interests}

The authors declare that there is no conflict of interests regarding the publication of this paper.

\section{References}

[1] H. Doust and E. Omatsola, "Niger Delta," in Divergent/Passive Margin Basins, J. D. Edwards and P. A. Santogrossi, Eds., AAPG Memoir 48, pp. 239-248, American Association of Petroleum Geologists, Tulsa, Okla, USA, 1990.

[2] H. Kulke, "Nigeria," in Regional Petroleum Geology of the World. Part II: Africa, America, Australia and Antarctica, H. Kulke, Ed., pp. 143-172, Gebrüder Borntraeger, Berlin, Germany, 1995.

[3] J. Hospers, "Gravity field and structure of the Niger Delta, Nigeria, West Africa," Bulletin of the Geological Society of America, vol. 76, no. 4, pp. 407-422, 1965.

[4] A. Kaplan, C. U. Lusser, and I. O. Norton, “Tectonic map of the world, panel 10," scale 1:10,000,000, American Association of Petroleum Geologists, Tulsa, Okla, USA, 1994.

[5] C. M. Ekweozor and E. Daukoru, "Northern delta depobelt portion of the Akata-Agbada petroleum system, Niger Delta, Nigeria," in The Petroleum System-From Source to Trap, L. B. Magoon and W. G. Dow, Eds., AAPG Memoir 60, pp. 341-358, American Association of Petroleum Geologists, Tulsa, Okla, USA, 1994.

[6] Petroconsultants, Petroleum Exploration and Production Database, Petroconsultants, Houston, Tex, USA, 1996.

[7] T. R. Klett, T. S. Ahlbrandt, J. W. Schmoker, and J. L. Dolton, "Ranking of the world's oil and gas provinces by known petroleum volumes," U.S. Geological Survey Open-File Report 97-463, 1997.

[8] M. R. Bhatia, "Plate tectonics and geochemical composition of sandstones," Journal of Geology, vol. 91, no. 6, pp. 611-627, 1983.

[9] B. P. Roser and R. J. Korsch, "Determination of tectonic setting of sandstone-mudstone suites using $\mathrm{SiO}_{2}$ content and $\mathrm{K}_{2} \mathrm{O} / \mathrm{Na}_{2} \mathrm{O}$ ratio," The Journal of Geology, vol. 94, no. 5, pp. 635650, 1986.

[10] J. D. Grigsby, "Detrital magnetite as a provenance indicator," Journal of Sedimentary Petrology, vol. 60, no. 6, pp. 940-951, 1990.

[11] Y. J. Joo, Y. I. Lee, and Z. Bai, "Provenance of the Qingshuijian Formation (Late Carboniferous), NE China: implications for tectonic processes in the northern margin of the North China block," Sedimentary Geology, vol. 177, no. 1-2, pp. 97-114, 2005.

[12] Z. Jin, F. Li, J. Cao, S. Wang, and J. Yu, "Geochemistry of Daihai Lake sediments, Inner Mongolia, north China: implications for provenance, sedimentary sorting, and catchment weathering," Geomorphology, vol. 80, no. 3-4, pp. 147-163, 2006.

[13] J. A. Winchester and P. A. Floyd, "Geochemical discrimination of different magma series and their differentiation products using immobile elements," Chemical Geology, vol. 20, pp. 325343, 1977.

[14] S. M. McLennan, S. Hemming, D. K. McDaniel, and G. N. Hanson, "Geochemical approaches to sedimentation, provenence and tectonics," in Processes Controlling the Composition of Clastic Sediments, M. J. Johnsson and A. Basu, Eds., vol. 284, Geological Society of America Special Paper, pp. 21-40, Geological Society of America, 1993.

[15] M. R. Bhatia and K. A. W. Crook, "Trace element characteristics of graywackes and tectonic setting discrimination of sedimentary basins," Contributions to Mineralogy and Petrology, vol. 92, no. 2, pp. 181-193, 1986.

[16] P. A. Floyd and J. A. Winchester, "Magma type and tectonic setting discrimination using immobile elements," Earth and Planetary Science Letters, vol. 27, no. 2, pp. 211-218, 1975. 
[17] P. A. Floyd and J. A. Winchester, "Identification and discrimination of altered and metamorphosed volcanic rocks using immobile elements," Chemical Geology, vol. 21, no. 3-4, pp. 291306, 1978.

[18] J. A. Winchester and P. A. Floyd, "Geochemical magma type discrimination: application to altered and metamorphosed basic igneous rocks," Earth and Planetary Science Letters, vol. 28, pp. 459-469, 1976.

[19] J. A. Pearce, "Sources and settings of granitic rocks," Episodes, vol. 19, no. 4, pp. 120-125, 1996.

[20] S. R. Taylor and S. M. McLennan, The Continental Crust: Its Composition and Evolution, Blackwell Publishing, Oxford, UK, 1985.

[21] S. M. McLennan, S. R. Taylor, M. T. McCulloch, and J. B. Maynard, "Geochemical and NdSr isotopic composition of deepsea turbidites: crustal evolution and plate tectonic associations," Geochimica et Cosmochimica Acta, vol. 54, no. 7, pp. 2015-2050, 1990.

[22] J. A. Hurowitz and S. M. McLennan, "Geochemistry of CambroOrdovician sedimentary rocks of the northeastern United States. Changes in sediment sources at the onset of Taconian orogenesis," Journal of Geology, vol. 113, no. 5, pp. 571-587, 2005.

[23] R. L. Cullers, "The controls on the major and trace element variation of shales, siltstones, and sandstones of PennsylvanianPermian age from uplifted continental blocks in Colorado to platform sediment in Kansas, USA," Geochimica et Cosmochimica Acta, vol. 58, no. 22, pp. 4955-4972, 1994.

[24] R. L. Cullers, "The geochemistry of shales, siltstones and sandstones of Pennsylvanian-Permian age, Colorado, USA: implications for provenance and metamorphic studies," Lithos, vol. 51, no. 3, pp. 181-203, 2000.

[25] R. L. Cullers and V. N. Podkovyrov, "Geochemistry of the Mesoproterozoic Lakhanda shales in Southeastern Yakutia, Russia: implications for mineralogical and provenance control, and recycling," Precambrian Research, vol. 104, no. 1-2, pp. 7793, 2000.

[26] R. L. Cullers, A. Basu, and L. J. Suttner, "Geochemical signature of provenance in sand-size material in soils and stream sediments near the Tobacco Root batholith, Montana, U.S.A.," Chemical Geology, vol. 70, no. 4, pp. 335-348, 1988.

[27] K.-I. Hayashi, H. Fujisawa, H. D. Holland, and H. Ohmoto, "Geochemistry of $\sim 1.9$ Ga sedimentary rocks from Northeastern Labrador, Canada," Geochimica et Cosmochimica Acta, vol. 61, no. 19, pp. 4115-4137, 1997.

[28] S. M. McLennan, W. B. Nance, and S. R. Taylor, "Rare earth element-thorium correlations in sedimentary rocks and the composition of the continental crust," Geochimica et Cosmochimica Acta, vol. 44, no. 11, pp. 1833-1839, 1980.

[29] R. J. Puddephatt, The Periodic Table of Elements, Oxford University Press, 1972.

[30] H. Wakita, P. Rey, and R. A. Schmitt, "Abundances of the 14 rare-earth elements and 12 other trace elements in Apollo 12 samples: Five igneous and one breccia rocks and four soils," in Proceedings of the Second Lunar Science Conference, pp. 13191329, Pergamon Press, Oxford, UK, 1971.

[31] R. L. Rudnick, "Restites, Eu anomalies and the lower continental crust," Geochimica et Cosmochimica Acta, vol. 56, no. 3, pp. 963970, 1992.

[32] K. C. Condie, M. D. Boryta, J. Liu, and X. Qian, "The origin of khondalites: geochemical evidence from the Archean to Early Proterozoic granulite belt in the North China craton," Precambrian Research, vol. 59, no. 3-4, pp. 207-223, 1992.
[33] S. M. McLennan, "Rare earth elements in sedimentary rocks: influence of provenance and sedimentary processes. Geochemistry and mineralogy of the rare earth elements," Reviews in Mineralogy and Geochemistry, vol. 21, pp. 169-200, 1989.

[34] S. M. McLennan and S. R. Taylor, "Sedimentary rocks and crustal evolution: tectonic setting and secular trends," The Journal of Geology, vol. 99, no. 1, pp. 1-21, 1991.

[35] S. M. McLennan and S. Hemming, "Samarium/neodymium elemental and isotopic systematics in sedimentary rocks," Geochimica et Cosmochimica Acta, vol. 56, no. 3, pp. 887-898, 1992.

[36] R. L. Cullers, T. Barrett, R. Carlson, and B. Robinson, "Rareearth element and mineralogic changes in Holocene soil and stream sediment: a case study in the Wet Mountains, Colorado, U.S.A," Chemical Geology, vol. 63, no. 3-4, pp. 275-297, 1987.

[37] D. J. Wronkiewicz and C. C. Kent, "Geochemistry and provenance of sediments from the Pongola Supergroup, South Africa: evidence for a 3.0-Ga-old continental craton," Geochimica et Cosmochimica Acta, vol. 53, no. 7, pp. 1537-1549, 1989.

[38] R. L. Cullers and J. L. Graf, "Rare-earth elements in igneous rocks of the continental crust: intermediate and silicic rocks-ore petrogenesis," in Rare Earth Element Geochemistry, P. Henderson, Ed., pp. 275-316, Elsevier, Amsterdam, The Netherlands, 1984. 

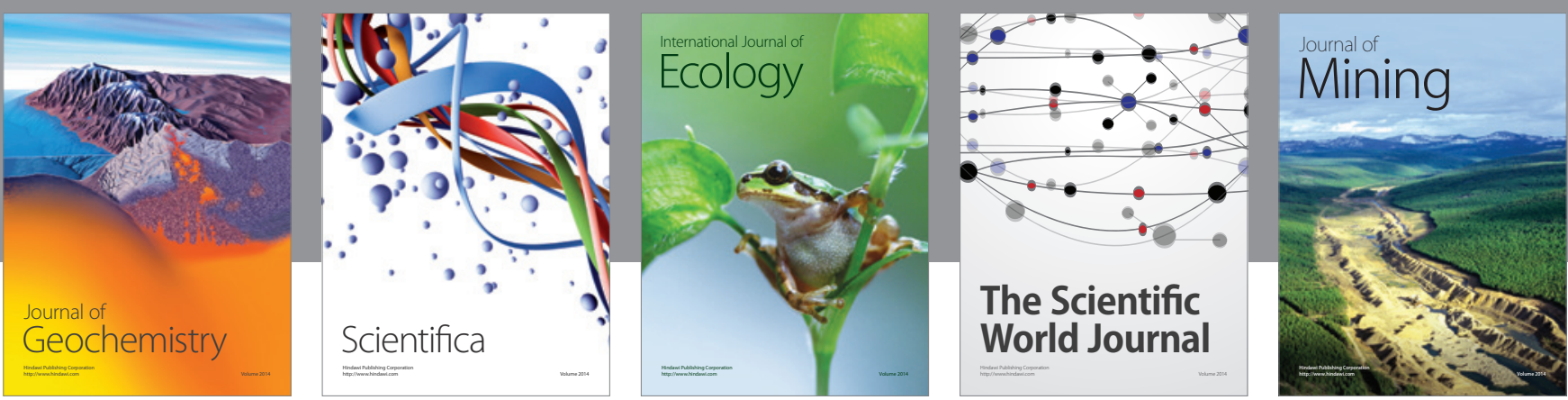

The Scientific World Journal
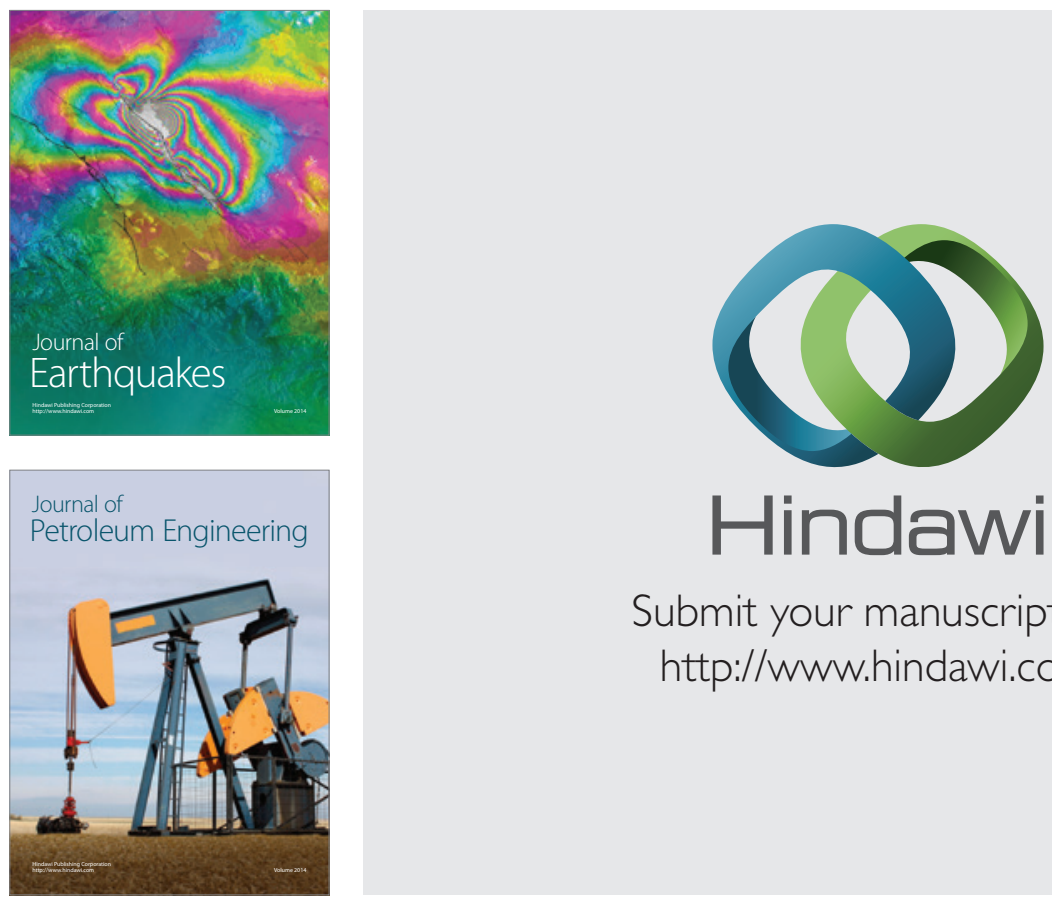

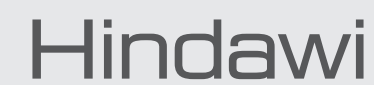

Submit your manuscripts at

http://www.hindawi.com
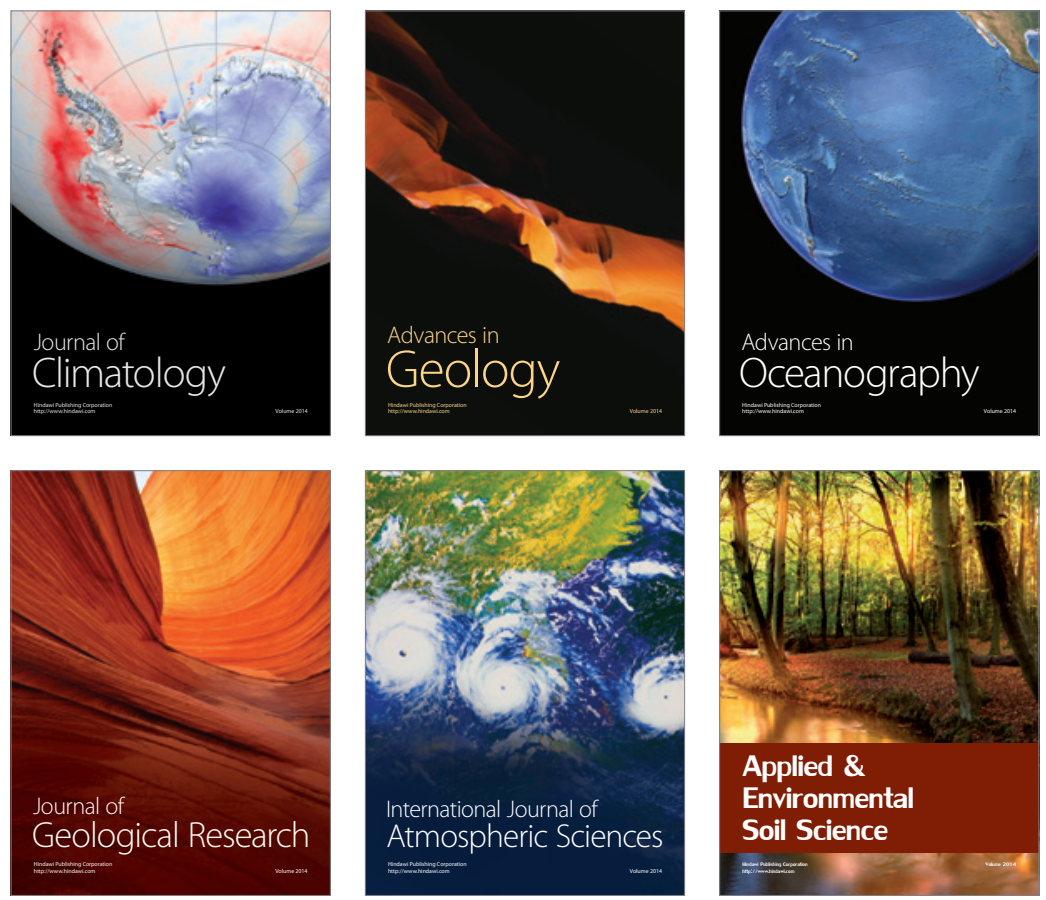
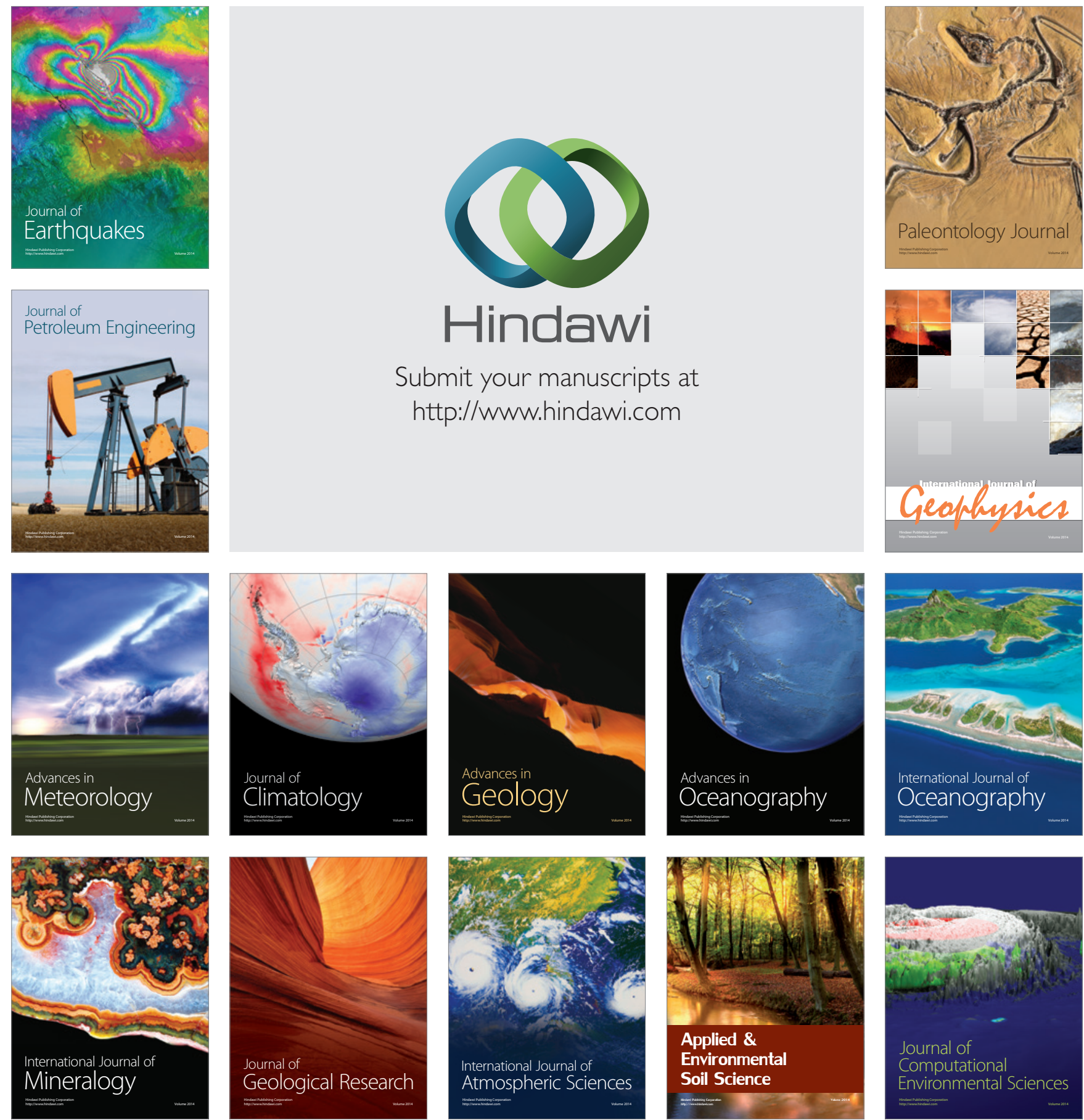